folk/ed. Derg, 2021; 27(4)-108. sayı

DOI: $10.22559 /$ folklor.1666

\title{
El Señor Presidente ve La Fiesta del Chivo Adlı Romanların Oluşumcu Yapısalcı Analizi*
}

\author{
A Genetic Structuralist Analysis of the Novels Mr. \\ President and The Feast of the Goat
}

Neslihan Kadıköylï̈**

$\ddot{O} \mathbf{z}$

Her ikisi de gençlik yıllarında kendi ülkelerinde diktatörlük rejimini tecrübe etmiş olan Miguel Ángel Asturias ile Mario Vargas Llosa diktatörlüğün yol açtığı yıkımı dile getiren başlıca romancılar arasında yer alırlar. Yazarların, yayımlandıkları dönemde büyük beğeni toplayan eserleri El Señor Presidente (Bay Başkan) ile La Fiesta del Chivo (Teke Şenliği) diktatörlüğün yarattığ1 korku toplumunu ve bunun sonuçlarını gözler önüne sererek karanlığı, zulmü, işkenceyi ve ölümü konu eder. Bu çalışma, söz konusu romanlar ekseninde diktatörlük temasını ve diktatör figürünü incelemeyi ve eserlerdeki toplumsal yapıları oluşturan anahtar kavramların neler olduğunu, nasıl bir ilişki bütünü sayesinde oluştuklarını açıklamayı hedeflemektedir. Çalışmada tarihsel ve toplumsal değerlerin oluşturduğu anlamlı yapıların eseri doğrudan etkilediğini ve

Geliş tarihi (Received): 8-02-2021 - Kabul tarihi (Accepted): 28-09-2021

* Bu çalışma Ankara Üniversitesi’nde 2017 yılında kabul edilen doktora tezinden üretilmiştir.

** Dr., Anadolu Üniversitesi Yabancı Diller Yüksekokulu.Anadolu University School of Foreign Languages nkadikoylu@anadolu.edu.tr. ORCID 0000-0002-0167-6702 
bu sebeple bir edebi eserin, eser-toplum bağlantısı ön planda tutularak incelenmesinin daha kapsamlı sonuçlar ortaya koyacağını ifade eden Fransız sosyolog ve eleştiri kuramcısı Lucien Goldmann'ın oluşumcu-yapısalcı yönteminden yararlanılmıştır. Ayrıca eserlerdeki otorite-itaat ilişkileri Erich Fromm'un düşünceleri doğrultusunda açıklanmaya çalışılmış, toplumsal yapı ve ilişkilere dair değerlendirmelerde ise Norbert Elias'ın düşüncelerine yer verilmiştir.

Anahtar sözcükler: Bay Başkan, Teke Şenliği, diktatör ve diktatörlük romanları, oluşumcu yapisalcılık

\begin{abstract}
Miguel Ángel Asturias and Mario Vargas Llosa, both have experienced the dictatorial regime in their own countries in their youth, are among the main novelists who express the destruction caused by dictatorships. The authors' novels El Señor Presidente ( $\mathrm{Mr}$ President) and La Fiesta del Chivo (The Feast of the Goat), received great acclaim at the time of their publication, describe the darkness, cruelty, torture and death by revealing the society of fear created by the dictatorship and its consequences. In the axis of these books, this study aims to examine the theme of dictatorship and the figure of the dictator and also to explain the key concepts that constitute the social structures in the novels. In the study, the French sociologist and critic theorist Lucien Goldmann's genetic structuralism method was used, who stated that the meaningful structures formed by historical and social values directly affect a novel, and therefore, examining a literary work with a focus on the connection between novel and society will yield more comprehensive results. Also, in the study, the authority-obedience relationships in the novels were tried to be explained in line with Erich Fromm's thoughts and Norbert Elias's theories were included in the evaluations on social structure and relations.
\end{abstract}

Keywords: Mr. President, The Feast of the Goat, dictator and dictatorship novels, genetic structuralism

\title{
Extended summary
}

Dictatorship and dictator novels, which emerged after the authoritarian regimes that began to spread out towards the beginning of the 20th century in Latin America, reveal a strong social critique with a comprehensive consideration of this period and express the destructive social processes, the deprivation of humanity and the social alienation caused by dictatorships. The first examples of this genre appear, from the second half of the 19th century, in the works of Argentine writers of the Romantic period. After these early works, almost a century passes until the publication of Miguel Ángel Asturias's El Señor Presidente (Mr President) in 1946. In $M r$. President, the attribution of extraordinary qualities to the dictator, as seen firstly in Valle-Inclán's novel Tirano Banderas, reaches its climax with the mythification of the dictator and becomes most commonly used feature in later works until the 1970's. After the year 1970 , in the novels of this (second) period, the dictator figure becomes more sophisticated. The dictator is now the protagonist and he is presented to the reader as an anti-hero with all his defects. Therefore, it is possible to evaluate the novels of this genre under two separate 
classifications as before and after the year 1970, and to separate the works written before this date as Dictatorship Novels and the ones after that date as Dictator Novels.

In this study, the principle elements of the social structure, its descriptive key concepts, the authority-obedience relations and the world views of the authors were discussed and tried to explain in the novels chosen as two sample works: El Señor Presidente (Mr President) and La Fiesta del Chivo (The Feast of the Goat). In this respect, it was aimed to explain, within the scope of these novels, the theme of dictatorship and the identity of the dictator in the Latin American novel, to understand the periods described in the books from the point of sociology of literature and to reveal the social structures changed during the process.

In the study, the French sociologist and critic theorist Lucien Goldmann's genetic structuralism method (structuralisme génétique) was used, who stated that the meaningful structures formed by historical, social and cultural values directly affect a novel, and therefore, examining a literary work with a focus on the connection between novel and society will yield more comprehensive results. Goldmann in this method tried to integrate the approaches of the formalists who emphasize only the analysis of the inherent features of a text with the point of view that sees the work as an expression of a collective consciousness. In this context, he brought together the sociology of literature and the structuralist analysis by proposing to examine the text in two stages: comprehension and explanation. Also, in the study, the authority-obedience relationships in the novels were tried to be explained in line with Erich Fromm's thoughts and Norbert Elias's theories were included in the evaluations on social structure and relations.

In terms of results, it has been defined that in both novels a coherent universe was created, and the social structures, relations and processes of society were consistently constructed as Goldmann stated. It was also seen that in both novels the society was alienated from its reality, mythicized the dictator in general and obeyed him unconditionally. However, it was noticed that Vargas Llosa -unlike Asturias- tried to destroy this point of view and portrayed the dictator as an impotent mortal rather than deified him. The main concepts that we have determined in the novels are the alienation, violence/torture, injustice, lack of communication, fear, captivity and death; and which concepts also reflect the social conception of that period in Guatemala and Dominican Republic. Additionally, The Feast of The Goat includes sexuality as a power tool and Erich Fromm's concept of automaton conformity.

Finally, another important point about the societies in both texts is that the internal structure of the regimes (especially in The Feast of the Goat) is shaped in accordance with Norbert Elias's theory of court society. In this direction, being close to the dictator and the way of life that he created around him has become a form of power in itself. It is noticed that this monarchic feeling of being with the dictator is widely accepted among the insiders. As pointed out by Elias (1983: 93), there is a distinctive social formation interlocked with intense competition between individuals around the king, caused by the desire for status and dignity. When evaluated in this context, the essence of the regimes in the novels is found in the subculture created by this new court society, and the conflicts between the elites, the rivalry and tension between them are an important power tool that keeps the king in power. 


\section{Giriș}

XIX. yüzyılın sonlarına doğru, diktatörlüklerin ve tek adam rejimlerinin Latin Amerika'da giderek artmasıyla birlikte ortaya çıkan ve yoğunlaşan diktatörlük romanları, edebi bir değer taşımalarının yanı sıra gerek toplumsal gerekse siyasal veriler sunmaları ve söz konusu süreçleri anlamaya katkı sağlamaları açısından önem taşırlar. Bu türün ilk örnekleri XIX. yüzyılın ikinci yarısından itibaren romantik dönem Arjantinli yazarların eserlerinde görülür. Bu ilk dönem eserlerinin ardından, 1946'da Miguel Ángel Asturias'ın Bay Başkan'ının yayımlanmasına kadar neredeyse yüzyıl geçer. Özellikle Ramón del Valle-Inclán'ın Tirano Banderas'ında (Zorba Banderas) rastlanan, diktatörün olağanüstü özellikler taşıması, Bay Başkan'da diktatörün mitleştirilmesi ile doruk noktasına ulaşır ve sonraki eserlerde de sıklıkla kullanılan bir öğe haline gelir. 1970 öncesi diktatörlük romanlarının, diktatöre uzak durma ve onu mitleştirme özelliklerini en belirgin şekilde kendinde taşıyan Bay Başkan, bu özelliği sebebiyle çalışmanın ilk eseri olarak seçilmiştir.

1970 sonrası ikinci dönemde ise diktatör figürünün ele alınışı giderek daha karmaşık bir yapıya kavuşur. Daha çok diktatörlüğü konu edinen ve diktatöre uzak durarak onu sislerin ardında tanrısal bir figür olarak betimleyen anlatı tarzı geride kalır. Diktatör artık başkahramandır ve oldukça ön plandadır; tüm ayrıntıları ve kusurlarıyla bir anti kahraman olarak okura sunulur. Dolayısıyla, bu türde yazılan romanları 1970 öncesi ve sonrası olmak üzere iki ayrı başlık altında değerlendirmek ve bu tarihten önce verilen eserleri diktatörlük romanları, sonrasındakileri ise diktatör romanları olarak ayırmak mümkündür. Bu çerçevede, ikinci dönem romanları (diktatör romanları) içinde hem diktatörü son derece yakın bir plandan okura aktaran hem de onu gerçekçi bir açıdan ele alarak tüm kusurlarıyla yaşlı, hasta, yalnız ve kimseye güvenmeyen bir karakter olarak tanıtan Mario Vargas Llosa'nın Teke Şenliği adlı romanı incelemenin ikinci eseridir. Ayrıca, aynı zamanda bir tarihi roman olan Teke Şenliği’nde diktatörün yalın bir gerçekçilikle sunulması da Bay Başkan ile arasında tam anlamıyla bir zıtlık yaratmış ve bu durum Teke Şenliği’nin ikinci eser olarak seçilmesinde belirleyici rol oynamıştır.

\section{Yöntem: Oluşumcu yapısalcı eleştiri}

Oluşumcu yapısalcılığın temelinde, eser ile onun doğuşuna yön veren toplumsal bağlam/ grup arasındaki ilişkiler üzerine düşünmek ve bu ilişkileri değerlendirmek yatar. Zira bir edebi eser, toplumsal koşulların ya da bir topluluk bilincinin basit bir yansıması değil, o topluluğu oluşturan öğelerden biridir ve bir düşünce ya da sanat ürünü gerçek anlamını bir yaşamın, bir davranışın oluşturduğu bağlamın bütünlüğü içine oturtulduğunda kazanmaktadır. Bu yüzden, oluşumcu yapısalcı analiz eserde bu kolektif bilinci yaratan en önemli öğelerden birini arar (ve görür) ve bu öğe, grubu oluşturan üyelerin düşündüklerinin, hissettiklerinin ve anlamını bilmeden yaptıklarının temelini oluşturur. Diğer bir deyişle, oluşumcu yapısalcı inceleme edebi eserin kendi iç tutarlılığını daha geniş bir tutarlılıklar ağıyla (tarihsel ve toplumsal bir ağ) ilişkilendirerek anlamaya/açıklamaya çalışır ve bu çerçevede, cevaplanması gereken asıl soru romanın yapısı ile bu yapının içinde geliştiği toplumsal yapı arasındaki ilişkidir (Goldmann, 2005: 24-78). 
Goldmann, edebi eseri ait olduğu bağlamla ilişkilendirerek açıklama yaklaşımına bir de tutarlılık kavramını ekler. Bu düşünceye göre, eseri oluşturan öğelerin bir iç tutarlılığ1, iç mantığ 1 vardır; bu öğeler kendi aralarında ve içinde yer aldıkları bütünün yapısına göre anlamlar kazanırlar (Rifat, 2008: 149-150). Ona göre büyük bir yapıt, kendine has nesnelere, kişilere, özerk bir evrene ve en önemlisi bir ideolojiye, dünya görüşüne sahiptir. Toplumsal, siyasal ya da ekonomik düzeylerde kendini var eden ve süreklilik gösteren bu dünya görüşü ise kendi içinde bir tutarlılık arz etmektedir. Bu çerçevede, her büyük yapıtın kendine ait bir iç tutarlılığı ve tutarlı bir dünya görüşü vardır ve böyle bir eser, toplumsal bilincin şekillendirdiği ve yazar aracılığıyla varlık bulan (yazar tarafından iç tutarlılığa ulaştırılan) bütünlüklü bir yapıya, toplumsal bir karaktere sahiptir. Bu doğrultuda, "büyük yazar, edebi eser alanında, grubun eğiliminin olduğu tarafa yatkın, tutarlı ya da tutarlıya yakın, düşünsel bir evren yaratmayı başarmış istisnai bir bireydir; eserin önemi ise, benzerleri arasında, tutarlılığa yakınlığı ya da uzaklığı ile ölçülebilir”' (Goldmann, 2005: 78).

$\mathrm{Bu}$ yöntem ile birlikte hem Marksist eleştiri hem de sosyolojik eleştiri tarihinde özgün bir yer edinen Lucien Goldmann, eseri ortak bir bilincin ifadesi olarak gören bakış açısıyla, yalnızca metin içi yapıların incelenmesine önem veren biçimcilerin yaklaşımlarını bütünleştirmeye çalışır. Edebi eseri içsel (anlama) ve dışsal (açıklama) olarak iki aşamada incelemeyi önerir ve edebiyat sosyolojisi ile yapısalcı incelemeyi bir araya getirir. Buna göre, eserdeki anlamlı yapıların aydınlığa çıkartılması bir anlama süreci; bu yapının daha geniş bir yapıyla bütünleştirilmesi ise bir açıklama sürecidir. Başka bir ifadeyle, eseri oluşturan yapıyı anlamak, bütünü teşkil eden unsurların diğer tüm öğeler ile birbirine bağımlı olarak ilerleyen ilişkilerini ve bu ilişkileri meydana getiren farklı süreçlerin doğasını ve anlamını kavrayabilmekten geçer. Bu çerçevede, eserin çözümlenmesinde ilk adım, metnin iç tutarlılığını ortaya koymaktır. Anlama (ya da yorumlama) aşaması metin içi bir süreçtir. Araştırmacı, kendini metin dışı bilgilerden soyutlayarak eserde yer alan anlamlı yapıların ayrıntılı bir saptamasını yapar ve böylece metnin içsel yapısını ortaya koymaya çalışır. Açıklama aşamasında ise metin, kendi dışında bulunan ama yine de içinde yer aldığı kabul edilen gerçeklikle (eseri kuşatan ve aşan bütünle) ilişkilendirilir. Metinde içsel yapıyı çevreleyen ve aşan toplumsal, ekonomik, siyasal ve tarihsel gibi dışsal bağlantılar bütünsel bir bakış açısıyla yorumlanmaya çalışılır. Ayrıca eserin doğuşunun açıklandığı bu aşamada sadece yazarı dikkate almak eksik olacaktır çünkü "bireyin sınırlı deneyini aşarak toplumsal bir grup ya da sınıf oluşturan kolektif öznedir tarihi yapan. Belli bir durumda kurulmuş dengeyi, (anlamlı yapıyı) özlemleri ve gerçek ya da mümkün bilinci doğrultusunda, bu özne dönüştürür” (Gürsel, 2007: 25). Bu sebeple, eserde anlam yaratan yapı (ya da yapılar) ile bir topluluk ya da bir toplumsal sinıf bilincini oluşturan düşünsel yapılar aranmalı ve ilişkilendirilmelidir (Rifat, 2005: 150-151).

\section{Anlama aşaması: İçkin çözümleme ${ }^{1}$}

\section{Anlatının bakış açıları}

Asturias, Bay Başkan' da çoğunlukla heterodiegetik (dış) anlatıcı türünü kullanır; bununla birlikte, homodiegetik (iç) anlatıcıdan da monologların, iç monologların ve diyalogların 
oluşturduğu doğrudan anlatımlar vasıtasıyla yararlanır. Bakış açısı genel olarak sıfır odaklanma şeklindedir. Bu konumdaki anlatıcı her şeyi rahatlıkla görür, tüm düşünce ve konuşmalardan haberdardır; bir kahraman kimliği kazanmaksızın aktaran, betimleyen ve değerlendirip yorumlayan bir sesten başka bir şey değildir. Tanrısal konumda olan bu dış anlatıcı, kahramanlardan daha çok şey bilir ve okura aktarır (Kıran, 2011: 142-143). El baile de Tohil (Tohil'in Dansı) adlı bölümde görüldüğü gibi, kimi yerlerde olacaklara dair ipuçları ${ }^{2}$ da verir: "Ölüm saatini gösteren bir yeraltı saatinin, yeraltı tik takları Cara de Ángel için vurmaya başliyordu" (Asturias, 2000: 307).

Benzer bir biçimde Teke Şenliği'nde de anlatıcı çoğunlukla heterodiegetiktir. Hangi bilginin okura aktarılacağına, hangilerinin gizleneceğine ve ne zaman okurla paylaşılacağına o karar verir. Anlatı boyunca bu dış anlatıcının bakış açısı değişiklikler gösterir ancak genellikle sıfır odaklanma söz konusudur; bu sayede her şeyi görür ve bilir. Öte yandan, özellikle diktatörün, suikastın ve sonrasının anlatıldığı bölümlerde anlatıcının birçok kez odak değiştirdiği ve kimi zaman suikastçılara, kimi zamansa diktatörün kendisine iç odaklanma yaptığı ya da diktatörün adamlarını onun bakış açısıyla aktardığı görülür. Bu bölümlerde bir nevi diktatörün bilincine yerleşerek, okuru, onun şüpheleri ve sorgulamaları ile baş başa bırakır: “Albay'1, bir böcekbilimcinin hangi familyadan olduğunu bilmediği bir böceği incelediği gibi inceleyerek keyifle güldü. Albay hakkında birçok söylenti vardı, özellikle de acımasızlığg konusunda. Bu görevde olan birisi için yararlıydı bu nitelik" (Vargas Llosa, 2003: 79). Teke Şenliği’nin bu özelliği, Bay Başkan ile arasındaki en önemli ve belirgin farktır. Asturias'ın eserinde anlatıcı diktatörden uzakta yer alır ve onu sislerin ardında, mistik, ulaşılması imkânsız bir kişi olarak okura sunar. Bu bağlamda Asturias, kendisinin de ifade ettiği gibi, diktatörünü efsaneleştirmek için özel bir çaba harcar ve bunun için Maya mitolojisinin, sürrealist anlatımların -kısmen de olsa- büyülü gerçekçiliğin oldukça ağır bastığı şiirsel bir anlatıyı tercih eder. Diktatör ile efsaneler arasında güçlü bir bağ kurar ve diktatörün toplum içinde kazandığg gücü -efsanelerle ilişkilendirerek- bir nevi kutsallık ya da ulaşılmazlık ile açıklar. Öte yandan Vargas Llosa diktatörün mitleştirilmesi algısını yıkmaya çalışır ve gerçekçi bir üslupla diktatörü yeryüzüne indirerek aklı özgürleştirmeye çabalar. Bu yüzden Teke Şenliği’nde -özellikle Trujillo ve çevresinin konu edildiği bölümlerde- anlatıcının sıfır odaklanmayı bırakarak adeta diktatörün bilincine yerleştiği ve onu şüpheleri, sorgulamaları, tedirginlikleriyle okura aktararak tanrısallıktan oldukça uzaklaştırdığı görülür. Asturias'ın diktatörü, mitleştirilmiş ve tanrısal özellikleri fark edilen bir roman kişisiyken, Trujillo kusur ve zayıflıkları olan ölümlü bir fanidir: "Dizlerinin bağı çözüldü. (...) Hemen biraz önce başlamış olmalıydı, hala ıslaktı. O anda duyarsız mesane hala su salıyordu. (...) Bir öfke dalgasıyla sarsıldı. İnsanlara hükmedebiliyordu, üç milyon Dominikliyi dize getiriyordu ama bedeninin bir yerlerindeki büzgenine söz geçiremiyordu" (Vargas Llosa, 2003: 155).

Son olarak, Teke Şenliği'ndeki bir diğer önemli nokta ise, "o" adılını kullanan dış anlatıcı haricinde, özellikle Urania'nın anlatıldığı kısımlarda fark edilen, yer yer ortaya çıkıp "sen" diye hitap ederek konuşan, sorular soran ve kim olduğu net olarak anlaşılamadığı için "belirsiz" olarak tanımlanabilecek bir anlatıcının varlığıdır: "Geri dönmekle iyi mi yaptın? Pişman olacaksın Urania” (Vargas Llosa, 2003: 12). Vargas Llosa’ya göre bu tür bir belir- 
siz anlatıcı tarafından kullanılan "sen”, kurgusal dünyanın dışında bulunan ve dayatıcı bir üslupla konuşan tanrısal anlatıcıya ait olabileceği gibi, şizofreniye kapılarak kendi kendine konuşan bir karakter anlatıcı da olabilir ve böyle bir belirsiz anlatıcının kimliğini tam olarak deşifre etmek mümkün değilse de anlatı içinde bulunan ufak ipuçlarından yola çıkarak bazı sonuçlara varmak mümkündür (Vargas Llosa, 1997: 33-35). Bu durumda, yukarıdaki alıntıda konuşan kimdir? Araya girerek yorumlar yapan, kahramana sorular soran ve onunla doğrudan konuşan bu anlatıcının, eserin tümüne hakim olan aynı tanrısal diş anlatıcı olduğu düşünülebilir; ancak aynı zamanda, Vargas Llosa'nın Madame Bovary üzerine yaptığı incelemesinde sözünü ettiği türde filozof bir tanrısal anlatıcı (Vargas Llosa, 1975: 223) olduğu da ileri sürülebilir. Kahramanının yaşamının en derinlerine ulaşabilmek için onun zihnine sızar, bilinçaltına yerleşerek iç sesi haline gelir. Onun anılarını, duygularını, düşüncelerini bilir ve anlatımı içeriden yapar; kahramanın zihnine girmek için ona o kadar çok yaklaşır ki anlatıcı ile kahraman arasındaki sınırlar belirsizleşir. Böylece, ikinci tekil kişi adılında sorulan sorular, ünlem cümleleri ve iç monologların aktarımı vasıtasıyla kahramanın psikolojik portresi giderek belirginleşir: "Ondan tiksiniyor musun? Nefret mi ediyorsun? Hala mı? Artık etmiyorum diyor yüksek sesle” (Vargas Llosa, 2003: 14).

\section{Zaman}

Bay Başkan dört kesitten (üç kısım ve bir epilog) oluşur. İlk iki kesit 21-27 Nisan olmak üzere yedi günü kapsar ve olayların gerçekleştiği 1916 yılı Verdun Savaşı'na gönderme yapılarak dolaylı olarak ifade edilir. III. kesit ise haftalar, aylar, yıllar ifadesiyle belirsiz birak1lır. Aynı şekilde epilog kısmı da tarihlendirilmez. Bölümlerin zamansal açıdan sıralanışı değerlendirildiğinde karmaşık ve okuru sürekli dikkatli olmaya zorlayan bir yol izlendiği görülür. Yer değiştirmelerle ${ }^{4}$ anlatının süredizimsel sırasının sık sık bozulduğu ve birbirini takip eden kimi bölümlerin aslında eşzamanlı olarak yaşandığı fark edilir. Ayrıca anlatıcının birçok yerde anakronik (zaman sapması içeren) anlatı düzenine başvurduğu fark edilir. Camila'nın geçmişi anımsayışı (Asturias, 2000: 91-97), Bayan Chón'un Cara de Ángel ile konuştuğu esnada Bay Başkan ile gençliğinde yaşadığı aşkın hatıralarından söz edişi (Asturias, 2000: 199) gibi bölümler eserde yer alan çok sayıdaki analepsis (geriye dönüş) örneklerinden birkaçıdır (Himelblau, 2000: 1018).

24 bölümden oluşan Teke Şenliği'nde ise, kurgusal ve tarihsel olmak üzere iki tür zaman mevcuttur. Şimdiki zamanda yaşanmakta ve eşzamanlı olarak öykülenmekte olan kurgusal zaman, eserdeki birinci anlatıdır ve Urania Cabral'in 1996 yılında Dominik Cumhuriyeti'ne gerçekleştirdiği bir haftalık seyahatin dördüncü gününde sabaha karşı saat dörtte uyanmasıyla başlayıp yaklaşık 24 saat sonra halası, kuzeni ve yeğeni ile yediği akşam yemeğinde diktatörün tecavüzüne uğrayışını anlatmasıyla son bulur. Anlatıcı Urania'nın ülkesini ziyaretini sıfır noktası alarak zamanda ileriye ya da geriye gitmek suretiyle olayları aktarır, süredizimsel sırayı takip etmeyerek analepsis ve prolepsis (ileriye sıçrama) teknikleriyle daha karmaşık bir yol seçer. Eserdeki tarihsel zaman ise, Trujillo’yu (ikinci anlatı) ve suikastçıları 
(üçüncü anlatı) konu edinir; tarih 30 Mayıs 1961'dir. İkinci anlatı olan Trujillo'nun hikayesi, 30 Mayıs günü sabaha karşı saat dörde doğru yatağında uyanmasıyla başlar ve aynı günün gecesi saat on civarında öldürülmesiyle son bulur. Üçüncü anlatı ise, suikastçıların okura tanıtılmasıyla birlikte aynı günün akşam saatlerinde başlar; diktatörün ölümünün ardından yaşanan olaylarla devam eder ve yaklaşık altı ay sonra sona erer.

\section{Uzam}

Bay Başkan'da uzam çok ayrıntılı bir şekilde verilmez ve roman dünyası yetersiz betimlemeden dolayı donuk bir görünüme sahiptir. Olayların yaşandığı ülkenin ya da şehrin adı doğrudan anılmasa da dış uzam 1916 yılının Guatemala şehridir. İç uzamlar ise, Plaza de Armas, Katedral, Pazar Yeri, La Merced semti, sokaklar, sahil, Başkanlık Sarayı, mahkeme salonu, Tus-Tep barı, Tatlı Büyü adlı genelev, tren istasyonu, liman, cezaevi, Yeni Ev kadınlar hapishanesi, karakol ve roman kişilerinin yaşadığg evlerden oluşur. Diktatörlüğün bir sonucu olarak, tüm uzamlara güvensizlik, korku ve ölüm hakimdir. Bu doğrultuda metinde gizemli, karanlık ve soğuk ortamların ön planda olduğu fark edilir. Kiliselerdeki mumların ve gölgelerin, zindanlardaki zifiri karanlık ortamların, sokaklardaki sessizliğin ve kiliselerden gelen çan seslerinin ülkedeki melankolik, acı ve korku dolu yaşamı vurguladığı görülür: “Tanrı'nın Kapısı'na bir gölge yaklaşıyordu. Dilenciler solucanlar gibi büzüldüler. Asker çizmelerinin gıcırtısına karanlık, belirsiz, sonsuz gece içindeki uğursuz bir kuşun iniltisi yanıt veriyordu” (Asturias, 2000: 12).

Benzer bir biçimde Teke Şenliği’nde de tüm uzamlara umutsuzluk, korku ve ölüm hakimdir. Birinci anlatıda, olayların geçtiği dış uzam Dominik Cumhuriyeti’nin başkenti Santo Domingo şehridir. Trujillo ile suikastçıların konu edildiği ikinci ve üçüncü anlatılarda da olaylar aynı yerde yaşanır ancak bu dönemde (1961 yılı) şehrin adı Trujillo Kenti'dir. Bu nedenle eserde şimdiki zamandaki Santo Domingo şehri ile geçmişteki Trujillo Kenti olmak üzere iki ayrı dış uzam yer alır. Şu anda oldukça canlı olan bu şehir, Trujillo Kenti olarak anıldığı zamanlarda karanlık, sıkıntılı, sessiz ve korku dolu bir mekandır. Dışarıya kapalıdır ve kapsanan bir uzamdır. Ancak sınırın diğer tarafı, Urania'nın kurtuluşu olan Amerika Birleşik Devletleri umuda açılan kapı ve kapsayan uzamdır. Eserdeki belli başlı iç uzamlar ise, Urania'nın babasının ve halasının evleri, Ulusal Saray, Radhames Malikanesi, Máximo Gómez Bulvarı, San Cristóbal yolu, La Cuarenta ve El Nueve cezaevleri, San Isidro Üssü, Balaguer'in çalışma odası, Casa de Caoba olarak sıralanabilir. Özellikle cezaevleri, iktidarın Dominiklilere yaşattığı zulmün birer simgesi gibidir ve buralarda yaşananlar vasıtasıyla rejimin dehşet verici ve insan yaşamını hiçe sayan uygulamaları ayrıntılı bir şekilde betimlenir: (...) Bir elektrikli iskemle seansı ile öteki arasında, Pupo'yu çırılçıplak sürükleyerek nemli bir hücreye götürüyorlardı. Orada kendine gelene dek başından aşağıya çirkef döküyorlardı (...) Birçok kez yenmeyecek şeyler doldurmuşlardı ağzına (Vargas Llosa, 2003: 401-402). Trujillo'nun, özel görüşmeleri için kullandığı evi olan Casa de Caoba ise bir diğer önemli iç uzamdır. Oldukça şık ve gösterişli bir biçimde döşenmiş olan bu yer, diktatörün gizli işler çevirdiği ve zor kullanarak getirttiği kadınlarla birlikte olduğu mekândır. 


\section{Diktatör figürleri ve diğer roman kişileri}

Bay Başkan' daki birincil karakterler Başkan, Cara de Ángel, Camila ve Askeri Savcı'dır. Ayrıca yazarın roman kişilerini; dilenciler, askerler, fahişeler, burjuvalar, din adamları gibi çeşitli toplumsal grup adlarıyla sınıflandırmış olduğu görülür. Bu doğrultuda, Askeri Savcı, Öğrenci, Kilise Memuru, Bay Başkan gibi karakter adları sembolik olarak kullanılmış; kimi zaman esperpentik ${ }^{5}$ bir biçimde (örn: Askeri Savcl, Bay Başkan) kimi zaman da gelecek umudu olarak (örn: Öğrenci) karakterize edilmiş ve sosyal statülerin ya da sınıfların birer örneğine dönüştürülmüşlerdir. Teke Şenliği' nde ise her anlatının ayrı bir başkahramanı vardır. Birinci anlatıda başkahraman Urania, ikincisinde Trujillo, üçüncüsünde ise suikastçılardır. Suikastçıların anlatıldığı bölümde, plana katılan çok fazla kişi olmasına karşın anlatıcı ilk etapta San Cristóbal yolu üzerinde Trujillo'nun Chevrolet'sinin geçmesini bir araba içinde beklemekte olan Antonio de la Maza, Amado García Guerrero (Amadito), Antonio Imbert ve Salvador Estrella Sadhalá'ya odaklanır. Bir yandan, her birinin Trujillo'dan intikam almak konusunda sahip olduğu kişisel hikayesini aktarırken, bir yandan da bu kişiler vasıtasıyla rejimin son yıllarında gerçekleşen çarpıcı olaylara yer verir. Plana katılan ve özellikle diktatörün öldürülmesinin ardından ön plana çıkan diğer suikastçılar ise, Savunma Bakanı José René Román, General Juan Tomás Díaz ve Başkan Balaguer'dir.

Bay Başkan' daki diktatör figürü anlatıda yalnızca yedi kez görünür. Esere adını vermesine ve olay örgüsünü harekete geçiren, ona yön veren en önemli karakter olmasına karşın başkahraman değildir. Gölgelerin ardında yaşayan gizemli ve uzak bir karakterdir. Sahip olduğu güç ve toplumda yarattığ 1 korku tüm anlatı boyunca hissedilir. Adeta tüm zamanlara yayılmış ve karanlık varlığıyla her yeri tamamen kuşatmıştır. Genel olarak öfkeli ve tahammülsüz bir portre çizer. Eserde kimi yerlerde bu öfkesi ile çocukluk ve ilk gençlik çağları arasında bağ kurulduğu görülür. Yoksulluk ve imkansızlık içinde geçen sıkıntılarla dolu o yıllar, yaşadığı o köy ve geçmişi duyduğu öfkeyi besleyen bir kaynak gibidir: "Doğduğu köyden söz açılınca kaşlarını çattı, hüzünle gölgelenmiş alnını kırıştırdı. Arkasında asılı duran Cumhuriyet haritasına dönüp köyünün adının yazdığı yeri yumrukladı" (Asturias, 2000: 265). İçindeki bu öfkenin yarattığı şiddet ve acımasızlık birçok bölümde ifade edilir. İktidarının gerçek ya da hayal ürünü düşmanlarına karşı "Kafalarını uçururum!” (Asturias, 2000: 37) ya da "Kafasını keserim!” (Asturias, 2000: 46) gibi tehditler dilinden düşmez. İçeride ve dışarıda onu devirmek isteyen düşmanları olduğuna takıntılı bir biçimde inanır ve bu takıntı daimi bir tedirginlik halini alır. "Dostlarım beni bırakıyor, düşmanlarımın sayısı artıyor." (Asturias, 2000: 266), “(...) düşmanlarım ve entrikaları (...)” (Asturias, 2000: 306) gibi ifadeleri sürekli tekrarlar. Düşmanlarına karşı çevresine topladığı ve çeşitli makamlara atadığı adamları; hiçbir şeye faydası olmayan, sadece ondan talimat alan işlevsiz bir kalabalıktan başka bir şey değildir.

Teke Şenliği'nde ise diktatör Trujillo eserin ikinci anlatısının başkahramanıdır ve aşırı cinsel isteği sebebiyle Teke (Chivo) lakabıyla anılır. Fakir bir aileden gelir ve kökeni anne tarafından siyahi Haitililere dayanır. Trujillo, siyasal, askeri, ekonomik ve cinsel açıdan ülkedeki en güçlü kişidir, ataerkil bir liderdir ve gücünü, Dominik halkı üzerinde mutlak bir kontrol kurarak kendini tek adam olarak dayatmak için kullanır. Cinsellik başta olmak üzere hiçbir konuda en ufak sınır tanımaz; arzuladığı her kadınla, özellikle de en yakınında çalışan 
adamlarının eşleriyle birlikte olur. Kadına yönelik bu davranışı yoluyla çevresindekilerin sadakatini ölçmeyi ve onları eşleri üzerinden toplum önünde küçük düşürmeyi hedefler. Adeta adadaki tüm kadınların kendisine ait olduğunu iddia eder. Bu duruma kimi zaman korkudan kimi zamansa çıkarlar sebebiyle ne itiraz edilebilir ne de engel olunabilir. Böylece bu kişiler ile rejim arasında son derece hastalıklı bir bağımlılık ilişkisi kurulur.

Öte yandan Trujillo'nun bu maço gücü tamamen mazide kalmış bir durumdur. Diktatör yaşamdaki son gününün anlatıldığı ikinci ve üçüncü anlatıda artık ilerleyen yaşı ve prostat kanseri nedeniyle idrarını tutamaz bir haldedir. Bu durumun ilk kez ortaya çıkışı ise diktatörün Urania ile geçirdiği gece yaşanmıştır. Bu yüzden, söz konusu gece diktatörün sonunu haber veren bir andır ve Trujillo'nun, onu var eden cinsel gücünü kaybetmesi iktidarsızlaşması ve dolayısıyla yaşamının, sembolik olarak, sona ermesi anlamına gelmektedir. Bu yaklaşımıyla Vargas Llosa, diktatörünü tanrılaştırmaktan ziyade gerçekçi bir zeminde ele alır. Onu hem hasta bir ölümlü olarak okurun karşısına çıkarır hem de geçmişte halk arasında kendisine atfedilen tanrısal özellikler nedeniyle oluşan imajını kırmaya çalışır: Endişeyle çarşafına baktı: Grimsi bir leke dokumanın beyazlığını bozuyordu. Gene mi gelmişti? (...) Lanet olsun! Lanet olsun! Bu, yıllardır satın alarak, baskı yaparak, öldürterek savaştığı ve yendiği yüzlerce, binlerce düşmanı gibi bir düşman değildi. Ta içinde yaşıyordu, etine işlemiş, kanına karışmıştı (Vargas Llosa, 2003: 26).

İncelenen metinlerdeki iki diktatör figürü de birçok açıdan birbirine benzerlikler gösterir. Her ikisi de aktif, disiplinli ve çalışkandır; siyasal, askeri, hukuki ya da ekonomik açıdan ülkenin en güçlü kişileridirler. Kalabalık ve coşkulu bir kitleye sahiptirler ve işbirlikçileri, cellatları ya da casuslarıyla her türlü meseleye doğrudan müdahale ederler. Ülke içinde ve hatta tüm dünyada onları devirmek için gece gündüz çalışan düşmanlarının olduğuna takıntılı bir biçimde inanmışlardır ve bu yüzden sürekli olarak güvensiz ve tedirgin bir ruh halindedirler. Düşmanlarını cezalandırmak için planlar yaparlar ve hiçbir şeye faydası olmayan, sadece aldıkları talimatla harekete geçen, onlara kulluk ve dalkavukluk derecesinde biat eden vasıfsız adamlarıyla suç işler, işkenceler yapar ve yeni faili meçhuller yaratırlar. Ayrıca eserdeki her iki diktatörde de görülen bir başka özellik ise, yoksul, taşralı ailelerden gelmeleri ve ironik bir biçimde kökenlerini nefretle yadsımalarıdır. Bay Başkan zorlu ekonomik koşullar altında eğitimini tamamlamış ancak maruz kaldığı önyargılı ve küçümseyici tavırlar hafızasında derin izler bırakmıştır. Bu yüzden, geçmişini hatırladığında öfke, keder ve nefretle dolar. Yoksul halkın sürdürdüğü yaşam koşullarına tamamen ilgisizdir ve hatta bunun da ötesinde halka düşmandır. Aynı şekilde Trujillo da yoksul bir aileden gelir ve tıpkı Bay Başkan gibi o da kendi kökenini yadsır: "Saçlarını tarayıp yirmi yıllık badem bıyığının ucunu düzelttikten sonra, annesinin ataları Haitili siyahilerden gelen, başkalarında olsun, kendinde olsun daima aşağıladığı esmerliğini örtene dek uzun uzun pudra süründü” (Vargas Llosa, 2003: 37). Kibirli bir biçimde Haitililere beslediği düşmanlığı her firsatta dile getirir ve gerçekleştirdiği Haitili Katliamı sebebiyle ülkesinin geleceğine büyük bir hizmette bulunduğunu iddia eder: "Bu ülke için ellerimi kana buladım. O siyahiler bir kere daha bizi sömürgeleştirmesinler diye" (Vargas Llosa, 2003: 201).

Diktatörlerin yakın adamları ise Bay Başkan'da Cara de Ángel, Teke Şenliği’nde Amadito'dur. İkisi de rejim tarafından onaylanmayacak kadınlara aşı olurlar. Bay Başkan'ın başkahramanı olan Cara de Ángel, diktatörün tüm kirli işlerini yapan ve onun sağ kolu olan 
düşmüş bir melek, cennetten kovulmuş bir anti kahramandır. Sevdiği kadından vazgeçmektense Başkan'a karşı durmayı ve hain olarak damgalanmayı göze alır. Amadito ise diktatörün emrine itaat eder ve Luisita'dan ayrılır. Ancak her ikisinin de eserin sonunda diktatörlerin karşısına çıkışları yalnızca kişisel husumetlerinden kaynaklanır; hiçbir ideolojik ya da entelektüel dönüşüm geçirmezler ve ortaya koydukları tepki hiçbir toplumsal anlam taşımaz.

Eserlerde kadın kurbanlar olarak karşımıza çıkan karakterler ise Camila ile Urania'dır. Her ikisi de rejimin yarattığı zengin ve elit tabakaya mensup ailelerden gelmektedirler ve yaşadıkları olayların ardından ülkenin ya da şehrin dışına çıkarak hayata tutunurlar. Camila oldukça naif ve kırılgan bir yapıdayken, Vargas Llosa'nın Urania'sı son derece güçlü bir kadındır ve anlatının en önemli kahramanlarından biridir. Bir zamanlar diktatörün en yakın adamlarından biri olan eski senatör Agustín Cabral'in kızı olan bu genç kadın, Trujillo diktatörlüğünün güçlendirdiği erkek egemen anlayış altında ezilen, özgürlüğü elinden alınan ve susturulan kadınları temsil eder. Onun yaşadıkları, dönemin kadınları açısından diktatörlüğün nasıl korkunç bir anlam ifade ettiğini gösteren çarpıcı bir örnektir. Ergenliğinin ilk yıllarında, babası tarafından rejime bağlılığının bir göstergesi olarak Trujillo'ya hediye edilen ve onun tecavüzüne uğrayan Urania, şans eseri hayatta kalarak Amerika Birleşik Devletleri’ne gitmeyi başarır. Sonraki dönemde yaşamında birçok başarı elde etmiş olmasına karşın psikolojik açıdan oldukça hasarlı ve yaralı bir kadındır. Geçmişin travmatik anılarıyla yüzleşmek ve hesaplaşmak niyetiyle diktatörün ölümünden yıllar sonra kısa bir ziyaret için ülkesine döner. Bu ziyaret boyunca kendi geçmişine ve bugününe dair yaptığ 1 sorgulamalar dikta rejiminin Dominiklilere yaşattığı zulüm ve acının canlı bir örneğidir.

Her iki metinde de rejimin karanlık işlerini yapan ve kötülüğü simgeleyen karakterler Bay Başkan'da Askeri Savcr, Teke Şenliği'nde ise Johhny Abbes 'tir. Bay Başkan'da geniş yer tutan Askeri Savcı yılan gözlü, kurbağa gözlü, baykuş suratlı olarak betimlenen kötü bir karakterdir. Savunmasız insanlar karşısında soğukkanlı ve acımasız bir sadist gibi davransa da Başkan'ın otoritesi karşısında gurursuz ve korkaktır. Her yaptığıyla insan haklarına karşı suç işleyen bu kamu görevlisi, dosyalarla dolu, pis bir evde yaşar; tiksinti uyandıran, açgözlü bir karakterdir: "İşe yaramaz kağıtların ve kirli karar dosyalarının arasında duruyordu; sessiz, çirkin, miyop ve pisboğazdı" (Asturias, 2000: 155). Özellikle tutuklu sorgularının yapıldığı bölümlerde, insan yaşamına değer vermeyen, acımasız ve empatiden yoksun haliyle ön plandadır. Askeri İstihbarat Teşkilatı'nın (SIM) şefi olarak görev yapmakta olan acımasız işkenceci ve katil Johhny Abbes ise rejimin tüm karanlığını üzerinde taşır. Trujillo'nun emriyle en korkunç infazları gerçekleştiren ve en ağır işkenceleri yapan/yaptıran bu kişi diktatörün “sadık bekçi köpeği”'dir (Vargas Llosa, 2003: 91). Abbes'in emrinde toplumun birçok kesiminden gelen ve ülkenin dört bir yanına dağılmış ajanlar (calié’ler ${ }^{6}$ ) bulunur ve bu kişilerin işlediği faili meçhul cinayetlerle, yaptığg türlü işkencelerle kötülük akıl almaz boyutlara ulaşır. Özellikle Trujillo'nun öldürülmesinin ardından José René Román'a yapılan ve günlerce hatta aylarca devam eden işkenceler, Abbes'in liderliğindeki kötülüğün en sert ifadesidir:

“Artık sonu çok yaklaşmıştı. Hayalarını bıçakla kesmediler, Taht’tayken makasla kestiler (...) Hayalarını ağzına tıktılar, o da yuttu, bunun ölümünü hızlandıracağını umuyordu. Ölüm. Hiçbir zaman ölümün bu kadar özlenebileceğini düşünmemişti” (Vargas Llosa, 2003: 403). 


\section{Toplumsal yapı ve ilişkiler}

Bay Başkan'da toplum, ezenler ve ezilenler, güçlüler ve güçsüzler, zenginler ve yoksullar gibi kutuplara ayrılmıştır. Ekonomik ve toplumsal eşitsizlik oldukça belirgindir ve günlük yaşam sıradan halk için her gün ara vermeden devam eden bir mücadele gibidir. Başkan'ın gücü, toplumsal yaşamın her alanında fark edilir ve bunu sadece onun çıkarına hizmet eden ve bu yönde şekillendirdiği askerine, polisine, güvenlik güçlerine borçludur. Diktatörün ülkesinde toplum; adaletsizlik, yasak ve korkuyla kuşatılmıştır; edilgen durumdadır ve tamamen paralize olmuştur. Onun talimatıyla suç işleyen, işkenceler ve faili meçhuller gerçekleştiren asker/polis çetelerinin sebep olduğu korku düzeni, kendisi dışında başka hiçbir şeyin hayatta kalmasına, kişilerin özgür bireyler olarak var olmasına olanak tanımaz. Cara de Ángel'in ağzından söylenen şu sözler buna iyi bir örnektir: "Yaşamak, adına yaşamak denen şey, her an şöyle tekrarlamak değildir: Bay Başkan'ın aklıyla düşünüyorum, sonra var oluyorum, Bay Başkan'ın aklıyla düşünüyorum, sonra var oluyorum..." (Asturias, 2000: 311) Eserde hiçbir toplumsal örgütlenme yoktur. Toplum; yalan, karmaşa ve korku içinde birbirinden uzaklaşmış, yalnız ve birbirine yabancı bireylerden meydana gelir. Tüm bu unsurların yarattığı toplumsal çözülme, yabancılaşma, kopukluk/iletişimsizlik, tıkanma/durağanlık, zindan/tutsaklık ve korku gibi anahtar kavramların etrafında şekillenir (Navarro, 1969: 59-76).

Yabancılaşma, özellikle kişiler arası ilişkilerde bağların hızla çözülüyor oluşu ya da hiç var olamaması nedeniyle oldukça dikkat çekicidir. Yalnız ve birbirine yabancı bir halde anlamsızlaşmış karakterlerle örülü anlatıda, aile fertleri ve arkadaşlar arasındaki kopuşlar çok keskin ve telafisi mümkün olmayacak şekilde gerçekleşir. Öykü boyunca anlatıya dahil olan diğer roman kişilerinin de çevreleriyle herhangi bir bağ kurmadıkları görülür. Kolektif bilinç ve eyleme geçebilme kapasitesi tamamen felç olmuştur ve roman kişileri yalnızlaşmış bireylerdir. Kahramanlar, Parrales Sonriente cinayeti nedeniyle doğrudan veya dolaylı bir şekilde bağlantılı olmalarına karşın ya birbirlerinin yaptıklarından habersizdirler ya da hiç tanışmazlar; kopuk ve iletişimsizdirler. Kişiler arasındaki görüşmeler kısa sürelidir ve bu kişiler çoğunlukla yeniden bir araya gelmezler. Bir araya geldiklerinde ise kimse diğerini dinlemez ve düşüncesini karşısındakine iletemez. Bu durum kısıtlı bir etkileşim yaratır ve kişilerin, etraflarında gelişen olaylar üzerine düşünmeyi bırakmalarına yol açar. General Canales ise çevresiyle iletişim kurarak belli bir süre boyunca birlik ve beraberlik oluşturabilen tek kişidir. Birkaç kişinin yardımıyla sınırın diğer tarafına kaçan ve burada -eserde adı geçmediği için bilinmeyen bir mekanda- isyancı güçlere liderlik ederek onları kısa bir süre için örgütlemeyi başaran Canales' in isyanı -idealist bir amaç gözetmeyip yalnızca kaybettiği itibarını geri kazanmayı amaçlıyor olmasına karşın- anlatı içerisinde yer bulan tek kolektif eylem örneğidir.

Eserdeki toplumsal yapıya dair bir başka önemli anahtar kavram ise tıkanma ve durağanlıktır. Roman kişileri ya cellat ya da kurbandırlar, ya yok eder ya da yok edilirler; bunun dışında bir varoluş sergileyemezler. Herhangi bir kişi, bütünleyici bir çaba içine girdiğinde ise, bunu destekleyecek olan ortamın yokluğu bu kişiyi boşlukta asıll, durağan bir halde bırakır. İyi olan hiçbir şey başarılamaz ve bu uğurda verilen çabalar da boşa çıkar. Her türlü ilerleyiş gerçekleşir gerçekleşmez durdurulur; toplum paralize haldedir. Hiç kimsenin bir mesleği, uğraşı, kişisel ya da toplumsal fayda sağlayacak herhangi bir fikri yoktur. Diğer 
dilencilerin zalimliklerinden bir türlü kurtulamayan, şehrin içinde tıkanıp kalan Pelele’nin durumunda görüldüğü gibi eserde huzur, kurtuluş ya da umut yoktur: “(...) Sanki koştukça sisten duvarları kendisinden daha da uzaklaşan bir hapishaneden kaçıyormuşçasına ilerliyordu" (Asturias, 2000: 22). Bu tıkanma ve durağanlık hali hem roman kişilerinin yaşamında hem de anlatıcının kullandığı ifadelerde birçok kez kendini gösterir. En belirgin örneklerden biri isyan ordusunun, Canales'in ölümünden haberdar olur olmaz taşlaşmasıdır: "Gece ilk garnizona saldırmaya hazır olan ordu durmuştu; tüm hareket yeteneğini alt eden garip, gizli bir gücün varlığını duyumsuyor, taşlaşıyordu” (Asturias, 2000: 295). Bu çerçevede verilebilecek bir diğer örnek de ne kadar yol alırsa alsın hiçbir yere varamayan, ilerledikçe gerileyen, hareket ettikçe durağanlaşan toplu taşıma araçlarıdır. Cara de Ángel'in trende limana doğru yol alırken tren gittikçe geride kalıyormuş hissine kapılması, kendi içine hapsolmuş ve hapsolduğu boşlukta asılı kalmış bir ortamı betimler: “(...) Hem trende gidiyor gibi hissediyordu hem de gitmiyormuş gibi... Sanki trenin ardında kalır gibiydi... Her defasında trenin ardında, trenin ardında, trenin ardında, trenin ardında, her defasında daha geride, her defasında daha geride (...)" (Asturias, 2000: 314) Aynı şekilde Pelele de düşünde trene binerek şehirden uzaklaşmaya çalışır ancak tren onu her seferinde aynı yere getirir: "Ama tren, ipin ucuna bağlanmış bir oyuncak gibi yine çıkış noktasına dönüyordu” (Asturias, 2000: 25).

Zindan ve tutsaklık da anlatıda geniş yer tutan kavramlar arasında yer alır. Cara de Ángel, Carvajal, Genaro Rodas, dilenciler, Fedina, Lucio Vásquez, Öğrenci, Kilise Memuru ve daha birçok kişi anlatının büyük bir kısmı boyunca zindanda tutsak edilirler ve Carvajal örneğinde görüldüğü gibi adeta diri diri gömülürler: "Daha şimdiden, içinde on iki ölüm mahkumunun mekan darlığından hareketsiz durduğu, sardalya gibi iç içe oturduğu üç metre uzunluğunda, iki buçuk metre genişliğinde bir hücreye gömmüşlerdi onu" (Asturias, 2000: 247). Zindana atılmamış olanlar ise ya kendi evlerine kapanırlar ya da bulundukları mekanlardan dışarı çıkmazlar. Bu kapanma hali bir başka anahtar kavram olan korkuyu işaret eder: "Barreño bitkin bir halde evine döndü. (...) Bir cani elinin onu boğmak üzere uzanacağ1 çatılara bakarak kapıyı kapattı ve odasındaki bir gardırobun arkasına gizlendi” (Asturias, 2000: 38). Anlatıcının korku kavramını tüm bu toplumsal çözülmenin temeline yerleştirdiği görülür. Öykünün başlangıcında yaşanan cinayetin ardından, ölüm ile tetiklenen ve yine ölümle sonlanacak olan bir dizi zincirleme olayın yaşanması ve gelişigüzel ya da absürd ${ }^{7}$ denebilecek bir biçimde cinayetlerin işlenmesi ölümü, dolayısıyla korku halini giderek ön plana çıkarır (Rodríguez Gómez, 2000: 815). Diktatör, ölüm ve şiddet ile güvensizlik hissini besleyerek korkuyu sürekli kılar ve böylece kendi varlığını dayatır. Ayrıca eserde birçok yerde aydınlığın yokluğu vurgulanır ve olaylar çoğunlukla gece yaşanır. Mosco'nun, Pelele'nin ölümü, Camila'nın kaçırılması, Fedina'nın işkence görmesi, tutuklamalar ve bu gibi daha birçok sahne karanlık ya da yarı karanlık mekanlarda gerçekleşir. Korku hissi adeta karanlık bir gölge gibi roman kişilerinin her adımının peşi sıra gider ve her birinin yaşamına nüfuz eder. Bu yüzden General Canales, Cara de Angel'in evinden çıkarken korku içindedir: “(...) Fakat kapıyı çekip sokakta tek başına kalınca, geçit törenlerine has o asker adımları, pazar yerine tavuk satmaya giden bir yerlinin adımları gibi küçüldükçe küçüldü’ (Asturias, 2000: 74). Suçsuz olduğu herkesçe bilinen Carvajal, işlemediği bir suç yüzünden yargılanırken bü- 
yük bir korku içindedir; Genaro Rodas evine dönerken yarı gerçek yarı düş içinde, yuvarlak, siyah ve camdan bir gözün (diktatörün her şeyi gören gözünü simgeler) kendisini izlediği hissiyle korkuya kapılır: "Bir göz... Yalnızca bir göz... (...) Bir kuşun yüreğinden büyük değildi ama cehennemden daha korkunçtu. (...) Hayır, bu Tanrı'nın gözü değildi, şeytanın gözüydü” (Asturias, 2000: 70-71). Eser, diktatörün toplumda yarattığı korkuyu ifade eden buna benzer birçok örnekle doludur. Başkan; devletin gücünü kullanarak, yargıyı esir alarak, tüm kurumları işlevsizleştirerek, sonu gelmeyen adaletsizliklerle, işkencelerle ve ölümlerle bir korku toplumu yaratır. Bu korku toplumunun içine düştüğü umutsuzluk ise 28. bölümde üç tutuklu (Kilise Memuru, Öğrenci ve Carvajal) sohbet ederlerken kim olduğu bilinmeyen dördüncü ses tarafindan şöyle dile getirilir:

“Özgürlük umudu yok arkadaşlar, Tanrı istediği sürece buna katlanmaya mahkumuz. Yurdun iyiliği için kafa yoranlar uzaklarda artık; kimileri yabancı diyarlarda sadaka dilenmekte, kimileri ise toplu mezarlarda çürümekte. (...) Katil kurşunlar yüzlerce insanın başını cezaevlerinin duvarlarında darmadağın ediyor. Sarayın mermerleri masumların kanıyla ıslandı. Gözler nerede arasın özgürlüğü?” (Asturias, 2000: 241).

Teke Şenliği’nde ise bölge halkı hakkında son derece az bilgi verilir, bunun yerine, diktatörün yakınında çalışan ya da çalışmış olan asker, siyasetçi, vb. kişilerin oluşturduğu toplumsal yapıdan daha çok bahsedilir. Ayrıca, rejim karşıtı faaliyetler yürüten ve 14 Hazirancılar olarak anılan hareket hakkında da kimi bölümlerde bilgi aktarılır. Bunun dışında sıradan halk ise, rejim tarafından sindirilmiş, adaletsizlik ve korku ile kuşatılmıştır. Çok fazla varlık gösteremez. Diktatör ülkedeki tek güçtür ve sözleri kanun hükmündedir. Askeri, polisi ve calié'leri ile bu gücünü toplum üzerinde sert bir biçimde uygular. Onun talimatıyla işkence ve cinayet suçları işleyen Askeri İstihbarat Teşkilatı'nın (SIM) ve başındaki Johnny Abbes' in sebep olduğu korku ortamı insanların özgür bireyler olarak varlık göstermelerine izin vermez. Bu çerçevede diktatörlüğün toplumda yarattığg etkiler, iktidar ve cinsellik, toplumsal yozlaşma, robot uyumluluğu gibi anahtar kavramlar etrafinda ele alınabilir.

İktidar ve cinsellik eserde yer alan en önemli kavramlardan biridir. Trujilo halkı sadece toplumsal açıdan baskı altına almakla kalmaz, davranışları ve uygulamalarıyla bireylerin özel yaşamlarını da ihlal eder. Ülkesindeki tüm kadınların vücudu üzerinde adeta hak sahibi olduğuna ve istediği gibi davranabileceğine inanır çünkü cinsel güç, Trujillo için sahip olduğu iktidarın simgelerinden biri ve dayanağıdır. Bu durumda kadın ve bedeni, iktidarını çevresindekilere gösterebileceği bir nesne/araç halini alır ve gözden düşmemek, rejime yakın durmak isteyen herkes diktatörün bu dayatmasına teslim olmak zorundadır. ${ }^{8}$ Öte yandan Trujillo, bir çeşit aile reisi rolü üstlendiğini iddia ederek her firsatta ulusal aile vurgusu da yapar ve eserde birçok yerde tekrarlandığı gibi kendisini Yeni Vatanın Babası olarak tanımlar, bu adla anılır. Ancak, sayısız cinsel şiddet ve tecavüz olayı ile bu sözde ailevi bağları bizzat kendisi ihlal eder. Kendisini ülkenin refahı ve geleceği için gerekli bir baba figürü olarak sunmasına karşın, özel yaşamında bakanlarının eşleri ve kızlarıyla ilişki yaşar ve yaşadığı her ilişkiyi bir zafer olarak görüp bunu alenen dile getirerek övünür. Bu şekilde hem kamusal yaşamda hem de Dominiklilerin özel yaşamında tek Şef'in, tek gücün kendisi olduğunu tekrar tek- 
rar yinelemiş olur. Toplumun aile bağlarını, ahlaki değerlerini zayıflatarak ve Dominiklileri sürekli aşağılayarak yıkıcı bir rol oynar. Eserde Urania'nın sözleri bu düşünceyi destekler niteliktedir: “(...) Ondan korkmakla kalmıyorlardı, seviyorlardı onu; tıpkı dayak ve cezaların onların iyiliği için olduğuna inandırılan çocukların otoriter ebeveynlerini sevdikleri gibi” (Vargas Llosa, 2003: 71-72). Bu çerçevede Trujillo, Abalos'un (1993: xviii) ifade ettiği siyasetçi tanımlamasına uyar: $o$, çocuklarının zihinsel olgunluğa erişmiş ve eleştirel düşünebilen bireyler olmasını istemeyen bir tür kötü baba gibidir. Etrafındakileri korkutarak/cezalandırarak kendisine tabi kılar, onları adeta çocuklaştırır ve (siyasal açıdan) olgunlaşmalarına engel olur. Otoritesi altındaki insanlar onun önünde tamamen iktidardan yoksun kalana dek onları aşağılamaya, kandırıp haklarını ve direnme kapasitelerini ellerinden almaya devam eder. $\mathrm{Bu}$ durum, -Canetti’nin (2006) dile getirdiği- iktidarın yıkıcı bir biçimde avını ele geçirme ve onu içe alma yöntemine benzer:

“Onları hayvan gibi kullanır (...) Yakınlarıyla konuşurken, onlardan koyun ya da sığır diye bahseder. Nihai amacı onları kendi içine almak ve özlerini emmektir (...) Artık işe yaramaz hale geldiklerinde tıpkı kendi dışkısından kurtulur gibi, yalnızca evinin havasin1 kirletmemelerine dikkat ederek onlardan kurtulur" (Canetti, 2006: 212).

Korku ya da menfaatler nedeniyle diktatöre ve sebep olduğu kötülüklere itaat ise toplumsal bir yozlaşmayı da beraberinde getirir ve bu durum, özellikle diktatörün kadınlarla olan ilişskisinde kendini gösterir. Şef'in destekçilerinin yozlaşmış hali ve ona karşı olan bağımlılıkları öyle bir noktaya varır ki, diktatörün talep ettiği cinsel birliktelikler çoğu kez söz konusu kadınların (mecburi) kabulü, eşlerinin (mecburi) boyun eğişi ya da (Urania örneğinde görüldüğü gibi) kimi zaman ebeveynlerin kılarını diktatöre hediye etmesi şeklinde gerçekleşir. Özellikle ailelerin, çocuklarına diktatör tarafından tecavüz edilmesine izin vermesi Teke Şenliği'nde tasvir edilen toplumun ne derece yozlaştığının en büyük göstergelerinden biridir:

“(...) Şef güzelliğin değerini bilir. Ona, Agustín size, sevgisinin ve bağlılığının kanıtı olarak hala bir señorita olan güzel kızını sunmak istiyor dersem geri çevirmez. (...) $\mathrm{O}$, şerefin ne demek olduğunu bilen mükemmel bir beyefendidir. Can evinden vurmuş olursun. Seni çağıracaktır. Elinden aldıklarını sana geri verecektir" (Vargas Llosa, 2003: 326-327).

Eserdeki bir diğer önemli anahtar kavram da Erich Fromm'a ait bir tanım olan robot uyumluluğudur. Fromm, Özgürlükten Kaçış adlı eserinde çağdaş insan açısından özgürlüğün iki yönünü ele alır ve özgürlükten kaçış mekanizmalarını yetkecilik, yıkıcılık ve robot uyumluluğu başlıkları altında inceler. Ona göre, çağdaş toplum yapısı içinde özgürlük insanı -olumlu ve olumsuz olmak üzere- iki farklı yönde etkiler. Yeni doğan bir bebek her ne kadar artık anneden ayrı bir biyolojik varlık olsa da işlevsel olarak annenin bir parçası olmayı sürdürür. Çünkü bebek bir süre boyunca başkalarını kendisinden ayrı varlıklar olarak algılayamaz ve kendisini evrenle karıştırmamayı öğrenmesi için birkaç yıl gerekir. Bebeğin anne ile kurduğu bu ilk bağ ona güven, bir yere ait olma, kendini bir şeyin parçası hissetme gibi duyguları verir. Bununla birlikte çocuk, kendisini dış dünyaya bağlayan bu ilk bağlardan ne ölçüde kurtulabilirse, o oranda özgürleşir; kurtulamaması halinde ise özgürlükten yoksun kalır (Fromm, 2016: 44-45). Bu ilk özgürlük -başlarda sebep olduğu yalnızlık, korku ve güven- 
sizlik duyguları nedeniyle- olumsuz özgürlüktür. Birey bu noktada eğer bu olumsuzlukları aşmayı başarıp olumlu özgürlüğe doğru bir gelişme gösteremezse, özgürlüğü tümüyle feda etmek ve ondan kaçmak zorunda kalır. Dünya ile kendi benliği arasında yeniden (ve sağlıklı) bir ilişki kuramamasından dolayı oluşan boşluğu ortadan kaldırarak yalnızlığını yenmek için çeşitli özgürlükten kaçış mekanizmalarını deneyerek içine düştüğü güçsüzlük duygusundan kurtulmaya çalışır. Olumlu özgürlük durumunda ise birey, "sevgi ve çalışma ile, coşkusal, duygusal ve zihinsel yetilerinin içten anlatımıyla, dünyayla kendiliğinden bir ilişki kurabilir; böylece bireysel benliğinin bağımsızlığından ve bütünselliğinden vazgeçmeksizin, bir kez daha, insanla, doğayla ve kendisiyle bir bütün haline gelir” (Fromm, 2016: 146-152).

Fromm'a göre, özgürlükten kaçış mekanizmaları içinde toplumsal önemi çok büyük olan robot uyumluluğu, çağdaş toplumun önemli bir kısmında görülebilen bir durumdur. Böylesi bir kaçış durumunda birey kendi olmaktan çıkar ve yalnızlık ya da güçsüzlük duyguları$\mathrm{n}$ yenebilmek için kendisinden ne bekleniyorsa onu yapar; toplumsal kalıpların kendisine sunduğu kişiliği tümüyle benimseyerek diğerleri gibi bir robot haline gelir (Fromm, 2016: 195-196). Fromm, kişide eleştirel düşüncenin bu biçimde bastırılmasının genellikle çok erken yaşlarda gerçekleştiğini yazar. Bu yüzden bireyin kararlarının çoğu, aslında kendisine ait değildir çünkü kişi soyutlanma korkusuyla ve yaşamına ya da rahatına gelebilecek tehditlerin verdiği endişe sebebiyle başkalarının beklentilerine uygun davranışlar sergiler. Kendisinden beklenene uyma davranışı göstererek gerçek arzularını bastırır ve başkalarının beklentilerini kendi öz arzularıymış gibi yaşar. Farkında olmadan özgün düşünme, duyma ve arzulama edimlerinin yerine sahtelerini koyarak, özgün benliğin yerini yapay benliğe bırakmasına yol açar. Özgün benliğin yitirilerek yerine yapay bir 'ben' algısının konulması ise, bireyi derin bir güvensizliğe sevk eder (Fromm, 2016: 202-212). Söz konusu birey,

“(...) temelde, başkalarının kendisinden bekledikleri şeyin bir yansıması olduğundan, kuşkularla doludur, bir ölçüde kimliğini yitirmiştir. Bu türden bir kimlik yitimi sonucunda ortaya çıan ani korkuyu yenmek için, uyarlanmak, uyum sağlamak, sürekli olarak başkaları tarafından onaylanmak ve kabul edilmek suretiyle kimliğini aramak zorunda bırakılmıştır. Kendisinin kim olduğunu bilmediğine göre, eğer onların beklentilerine uygun edimlerde bulunursa, onlar bilecektir; onlar bilince de kendisi de kim olduğunu bilecektir; bunun içinse onlara inanması yeterlidir" (Fromm, 2016: 213).

Sonuç olarak, olumsuz özgürlük ile baş edemeyip robotlaşan, giderek kimliğini yitirerek sonsuz bir güvensizlik ve çaresizlik sarmalına giren birey bu duygunun üstesinden gelebilmek için bir başka otoriteye boyun eğmeye hazır hale gelir. Fromm'un bu görüşleri eserde Savunma Bakanı Rene Román'ın, diğer askerlerin ve kitlelerin Trujillo diktatörlüğü karş1sındaki tutumlarını kimi yönlerden açıklayabilecek niteliktedir. Özellikle Rene Roman'ın durumu, toplumda diktatöre boyun eğişin ve kabullenişin bir örneklemi gibidir: “(...) Birçok subay, birçok Dominikli gibi Trujillo’nun karşısında cesareti ve onur duygusu gölgeleniyor, aklı ve adaleleri paralize oluyor, üstüne bir uysallık çöküyordu” (Vargas Llosa, 2003: 377). Askeri açıdan oldukça kritik bir görevde bulunan ve suikast planının başarısı konusunda kilit rol üstlenen Rene Román, Trujillo tarafından sürekli aşağılanan ve küçümsenen bir karakterdir. Büyük olasılıkla bu yüzden komploya katılmıştır ve plana göre suikastçılar diktatörü 
öldürdüğünde bir darbe ile yönetimi ele geçirecektir. Ancak Rene Román, Trujillo'nun öldürülmesinin ardından çekingen ve kararsız davranarak üzerine düşeni yerine getirmez ve kavranması zor bir durum yaratır. Planın başarıyla sonuçlanması ve böylece hem kendisinin hem de diğer arkadaşlarının yaşamının riske girmemesi adına ne yapması gerektiğini bilse de tam tersi şekilde davranır. Zira Trujillo, Savunma Bakanı için -bunun farkında olmasa da- bir dayanak noktasıdır. Terfi etmesi, siyasal konumu, yaşam biçimi ve hatta kendi varlığı diktatörün etrafında şekillenir. Bu yüzden bağımsız bir biçimde davranmayı başaramaz ve suikastın ardından kararlaştırılan planı uygulamaya koyamaz. Yıllar boyunca sürekli emir almaya alışmış olan bu kişi yaşanan otorite boşluğuyla birlikte adeta paralize olur:

"Kendi geleceği, ailesinin geleceği, komployu yapanların ve sonuçta bütün Dominik Cumhuriyeti'nin geleceklerinin belirlendiği o anda ve o anı izleyen dakikalar ve saatlerde General José René Román tam bir zihin açıklığıyla ne yapması gerektiğini çok iyi kavradı. Peki neden tam tersini yaptı? O anı izleyen aylarda kendine bu soruyu birçok kez soracak ama yanıtını bulamayacakt"1 (Vargas Llosa, 2003: 382).

Son olarak, her iki metindeki toplumlara dair bir diğer önemli nokta da rejimlerin (özellikle Teke Şenliği'nde) iç yapısının Norbert Elias'ın saray toplumu kavramına uygun olarak şekillenmiş olmasıdır. Bu doğrultuda, diktatöre ve onun çevresinde oluşturduğu yaşayış biçimine yakın olmak kendi içinde bir iktidar biçimi halini almıştır. Diktatörün yanında bulunmanın verdiği bu monarşik hissin, -kendini bir saraylı olarak tanımlayan Joaquín Balaguer'de ve Cara de Ángel'de olduğu gibi- içeridekiler arasında büyük bir kabul gördüğü fark edilir. Elias'ın ifade ettiği gibi (1983: 93) kralın çevresindeki bireyler arasında, statü ve itibar arzusunun -ve hatta eserlerde görüldüğü gibi bir yanda korku, bir yanda da kıskançlık, hırs ve öfkenin- yol açtığı yoğun rekabetle birbirine kenetlenmiş olan kendine özgü bir toplumsal oluşum bulunur: “(...) İktidarının daha ilk günlerinden beri Trujillo’nun önemli görevler için güvendiği ve yetenekli kişilere tanıdığı ayrıcalıklardan bol bol nasibini almıştı. Üstelik bu özel kulübe alınanların en yeteneklilerinden biriydi” (Vargas Llosa, 2003: 141). Bu çerçevede değerlendirildiğinde, eserlerdeki rejimlerin özü, bu yeni saray toplumunun oluşturduğu alt kültürde bulunur ve saray çevresindeki elitler arası çatışmalar, aralarındaki rekabet ve gerilim kralı iktidarda tutan önemli bir iktidar aracıdır. Diğer bir deyişle, elitlerin birlik olması tek adam iktidarı için bir tehlike anlamına gelirken, bu gruplar arasındaki dışarıya taşmayan kontrollü bir gerilim söz konusu iktidarın kuruluşu ve devamı için önemli bir etkendir (Elias, 1983: 278). Bu yüzden, parlamenter çok partili sistem ile tek partili diktatoryal sistem arasındaki önemli değişkenlerden biri, tek adam iktidarında bir takım çıkar grupları arasındaki çatışmaların, diktatöre yakın olan dar elit çevre içinde ve sarayındaki kulislerin ardında gerçekleşiyor ve çözümleniyor olmasıdır (Elias, 1983: 282). Saray ve saray adabı, içerde var olan çatışmaları gizlemekte, onları denetim altında tutmaktadır. Bu açıdan bakıldığında, incelenen metinlerde elitler arası çatışmaların yer bulduğu ve hatta bizzat diktatör tarafından belli bir dereceye kadar canlı tutulduğu, teşvik edildiği fark edilir. Bu kontrol sağlanamadığında ise, -Teke Şenliği'nde eserin sonunda olduğu gibi- sarayın elitlerinin kendi aralarındaki çatışmalarda uzlaşmayı başarıp harekete geçtikleri ve diktatörü bertaraf ettikleri görülür: "Öldü köpoğlusu, öldü” ( Llosa, 2003: 235). 


\section{Açıklama aşaması: Aşkın çözümleme}

\section{Anlatının kaynağı}

Bay Başkan'da anlatının kaynağı, Guatemala'da 22 yıl boyunca sürmüş olan Manuel Estrada Cabrera diktatörlüğü ve bu dönemde uygulanan şiddet nedeniyle toplumun üzerine çöken korku ve karanlıktır. İktidarına yönelik her türlü muhalefeti yok eden Cabrera siyasi cinayetleri, cezaevinde işkenceleri ve muhaliflerini kurşuna dizmeyi yıllar boyu sürdürür (Pineda, 1902: 3-34). Cabrera diktatörlüğünün bu dikkat çeken şiddet niteliği, Asturias'ın romanında -cezaevi tasvirlerinin ve işkencelerin aktarılışıyla- oldukça ön plana çıkan bir özelliktir. Bu dönemde istihbarata verilen aşırı önem de romana kaynaklık eden bir başka unsurdur. Estrada Cabrera ülkede, kendisine gizli bilgiler ileten ihbarcı ajanlarla dolu örümcek ağı gibi bir istihbarat kurar. Herkesin birbirini izlediği ve ihbar ettiği bu düzen sayesinde uzun yıllar boyunca muhalefeti kontrol altında tutmayı başarır. Diktatörün hafızası; Guatemalalıların bilgileriyle, isimleriyle, ünvanlarıyla ve çeşitli hikayelerle doludur (Ospina, 1929: 103-104). Şilili yazar ve gazeteci Hübner de bu konuyla ilgili olarak, Cabrera'nın bir memuru, bir başka memur aracılığıyla gözlediğini; bir casusu diğer casusla izlediğini ve hatta bunu aileler, arkadaşlar arasına bile taşıdığını ve böylece kimsenin kimseye güvenmeyip herkesin birbirinden şüphe duyarak yaşamaya başladığını yazar (Hübner, 1992: 376). Bu doğrultuda eserde de görünmez bir iletişim ağı vatandaşların gizli iç dünyasında neler olup bittiğini bile dikkatle izleyen Başkan'a her şeyi bildirmektedir. İnsanlar birbirinin muhbiridir; aynı ev içinde yaşayan kişiler bile birbirini gözetler, bilgi toplar: "Orada, ev sahibi ile hizmetçi kızı gözetleyen aşçı kadının ve ev sahibi ile aşçı kadını gözetleyen hizmetçi kızın bana bildirdiklerine göre, Cara de Ángel, çalışma odasında General Canales ile yaklaşık kırk beş dakika görüşmüştür” (Asturias, 2000: 79).

Teke Şenliği ise konusunu Dominik Cumhuriyeti'nde 1930-1961 yılları arasında yaşanmış olan Trujillo diktatörlüğünden alır. Romanın temel kaynağını (tamamen kurgusal ve sembolik bir karakter olan Urania'nın bölümleri hariç) diktatörün suikast sonucu öldürüldüğü 30 Mayıs 1961 günü yaşanan olaylar oluşturur. Birçoğu geçmişte diktatörün yanında çalışmış olan ve içlerinde subayların da yer aldığı bir grup Dominikli, otuz bir yıl boyunca tüm ülkeyi boyunduruk altına alan bu rejimi sona erdirebilmenin tek yolunun Trujillo'nun fiziksel olarak yok edilmesi olduğunu düşünür ve bu doğrultuda örgütlenir. Yapılan planlar neticesinde Trujillo, 30 Mayıs 1961 günü -CIA tarafından da desteklendiği iddia edilen (Villalona, 2012: 149-150) - bir suikast sonucunda öldürülür. Eserde de adları sıklıkla anılan Antonio de la Maza, Juan Tomás Díaz, Antonio Imbert, Luis Amiama Tió, Salvador Estrella Sadhalá, Huáscar Tejeda, Amado García Guerrero, Pedro Livio Cedeño, Modesto Díaz, Luis Manuel Cáceres, Miguel Ángel Báez Díaz ve Antonio García Vásquez, Trujillo’nun yaşamına son veren bu eylemin birincil yöneticileri ve uygulayıcılarıdır.

Urania'nın öyküsünün anlatıldığı bölümlerde romana kaynaklık eden öğe ise diktatörün çevresindeki kadınlara uyguladığı cinsel şiddettir. Şef'in gaddar ve empatiden yoksun tavrının özellikle iktidarda olduğu dönemde kadınlara karşı takındığı maço ve sınır tanımaz davranışlarında kendini gösterdiği bilinmektedir. 1943 yılında Trujillo'nun özel sekreterliğini yapmış olan (sonraki süreçte Trujillo karşıtı olur) José Almoina'nın ifade ettiğine göre Trujillo garip dürtüleri olan bir kişidir ve iktidara gelişi bu dürtülerin beslenmesine, giderek 
güçlenmesine olanak sağlamıştır. Kendisine övgüler yağdırmayan ya da onunla birlikte olmayı reddeden kadınları türlü şekillerde cezalandırabilecek, toplum önünde küçük düşürebilecek, taciz edebilecek ve hatta faili meçhul bir biçimde katledebilecek kadar nefret doludur (Almoina, 2011: 40-48).

\section{Yazarın yaşam öyküsü ve dünya görüşü}

Miguel Ángel Asturias, 19 Ekim 1899'da avukat Ernesto Asturias Girón ile öğretmen María Rosales'in çocuğu olarak Guatemala'da dünyaya gelir. Yazarın doğumu, bir yandan Amerikan emperyalizminin ortaya çıktığ 1 , bir yandan da Guatemala tarihinin en uzun ve ac1masız diktatörlüklerinden birinin yaşandığı döneme denk düşer. Cabrera diktatörlüğü, birçok Guatemalalı gibi Asturias ailesinin yaşamını da doğrudan etkiler. Yoksulluk ve zorluklar içinde geçen çocukluk ve ilk gençlik yıllarının ardından 1922 yılında Guatemala'da hukuk eğitimini tamamlayarak Avrupa'ya gider, uzun yıllar Paris'te yaşar. 9 Haziran 1974'te Madrid'te kaldırıldığg hastanede vefat eder ve vasiyeti üzerine Paris’teki Père Lachaise Mezarlığı'na defnedilir.

Asturias 1924'te başlayan Avrupa yıllarıyla birlikte yazınsal açıdan büyük bir dönüşüme uğrar. Paris’te yaşadığı dönemde avangard sanatçılarla bir araya gelir. Bu şehirde edindiği tecrübeler ve tanıştığı sanatçılar sayesinde, Guatemala kültürünü özgün ve yeni bir bakış açısıyla anlatmasını sağlayacak olan sürrealizm, ekspresyonizm ve dadaizm gibi avangard akımları doğrudan tanıma firsatı yakalar. Edebiyat eleştirmeni Fernando Feliu-Moggi’ye göre bu dönem, yazarın yaşama bakışında bir çeşit ikili bilinç ${ }^{9}$ oluşturur. Böylece Guatemala kültürünü, mestizo'lar1 ${ }^{10}$ ve yerlileriyle birlikte bir bütün olarak kavramaya başlar ve kendi gerçekliğine başka bir dünyanın, Avrupa'nın tuttuğu aynadan bakar. Dünyayı Maya duyarlılığıyla algılamaya fakat bunu ifade ederken -Bay Başkan'da görüldüğü gibi- sürrealizm ve ekspresyonizmin ifade çeşitliliğini kullanmaya başlar (Feliu-Moggi, 2000: 570-572).

Asturias'ın yazınsal üretimi çok yönlüdür; deneme, öykü, roman, şiir ve tiyatro oyunlarından edebiyat eleştirisi ve gazete yazılarına kadar birçok alanda çalışmalar yapar. Bay Başkan'dan sonraki romanı Hombres de maíz'de (Mısır İnsanları) Mayaların kutsal kitabı Popol Vuh'un üslubundan yola çıkarak büyülü bir atmosfer yaratır, anlatıya mitolojik unsurlar katar ve Mayaların gizemli dünyasına dalar. Yazarın 1940'lı yıllarda özellikle Trilogía bananera (Muz Üçlemesi) adıyla anılan romanlarıyla birlikte ise, eserlerinde siyasal ve toplumsal ögeler giderek ayırt edici bir nitelik kazanmaya başlar. Ülkesinin içinde bulunduğu toplumsal ve ekonomik koşullar yazarı, muz şirketi ve muz plantasyonları üzerine yazmaya ve Amerika Birleşik Devletleri'nin ekonomiyi, siyaseti kontrol eden sömürgeci anlayışını eleştirmeye iter.

Mario Vargas Llosa ise 28 Mart 1936 yılında Peru'nun güneyinde yer alan Arequipa kentinde dünyaya gelir. Yazarın ilk gençlik yıllarında kendini göstermeye başlayan edebiyat ve şiir tutkusu, 1953 yılında San Marcos Ulusal Üniversitesi'nde edebiyat ve hukuk eğitimi almaya başlamasıyla devam eder. Bu süreçte Peru'da hüküm süren baskı rejiminin yarattığı siyasal gündem ve tarihsel bilinç yazarı siyasetle yakından ilgilenmeye yönlendirir ve bu ilgi onu, Peru Komünist Partisi'ne (Partido Comunista Peruano) yaklaştırır. Zira bu tarihlerde, yazarın ülkesi Peru'da bir diktatörlük (1948 yılından 1956'ya kadar süren Manuel Arturo 
Odría diktatörlüğü) yaşanmaktadır. Ayrıca, Vargas Llosa'nın bu yıllarda tecrübe ettiği deneyimlerinin onu, şiddete ve diktatörlüğe büyük bir tepki göstermeye yönelttiğini ve sonraki yıllarda da diktatörlük temasını - başta Conversación en La Catedral (Katedralde Sohbet) ve Teke Şenliği olmak üzere- bazı eserlerinde ele almaya sevk ettiğini düşünmek mümkündür.

Yazar 1959 y1lında Javier Prado bursunu kazanarak Madrid Complutense Üniversitesi'nde doktora eğitimi almak üzere İspanya’ya gider. Böylece 1959-1974 yılları arası -ülkesine zaman zaman dönse de- hayatı genel olarak Avrupa'da geçer; Madrid, Paris, Londra ve Barselona'da yaşar. Bu yıllarında, onu edebi teknik ve anlatım özellikleri açısından geliştirecek olan Sartre, Flaubert, Faulkner gibi yazarları okumaya yönelir; bu yazarların eserlerinden büyük ölçüde etkilenir ve edebi açıdan giderek üretken olacağı bir döneme girer. 1963 yılında yayımladığı ilk romanı La ciudad y los perros (Kent ve Köpekler) sayesinde büyük başarı elde edeceği ve edebiyat çevrelerinde adını duyuracağı dönem başlar.

1974 'te yeniden ülkesine dönen yazarın 80'li yılların sonlarına doğru giderek siyasete yaklaşmaya başladığı görülür. Bu süreçte edebiyat ve gazetecilik vasıtasıyla ifade ettiği bireysel, toplumsal, siyasal kaygılarını ve sorgulamalarını siyaset alanına taşır ve bunun neticesinde 1990 yılında başkanlık seçimlerine aday olur, ancak, Demokratik Cephe'nin (FREDEMO) adayı olarak katıldığı seçimlerde başarılı olamaz. Seçimlerden kısa bir süre sonra Peru'dan ayrılır ve Avrupa'ya (Londra ve Madrid) dönerek kendini tamamen edebiyata adar. Diktatörlüklere ve şiddete karşı duruşunu her firsatta ifade etmeyi sürdüren yazar 2010 yılında, iktidar yapılarının haritasını çıkarması ve bireyin direniş, isyan ve yenilgilerinin keskin tasvirlerini yapması sebebiyle Nobel Edebiyat Ödülü'ne layık görülür. Halihazırda Madrid'de yaşamını sürdürmektedir.

\section{Simgesel çözümleme}

Asturias Bay Başkan'da mitolojiden ve mitolojik simgelerden yararlanır. Guatemala toplumunu, atalarından kalan kültürel mirasın bir sentezi olarak gören yazar eserde, Hristiyan ve Maya mitolojilerine ait ögeleri bir araya getirir. Eserin özgün ismindeki señor kelimesi, sayın ya da bay anlamında kullanılmasının yanı sıra, Hristiyanlıkta tanrı anlamına da gelmektedir. Ancak Bay Başkan kötüdür, romanın karanlık evreninin şeytani tanrısıdır. Ayrıca, diktatöre hitaben söylenen "Efendimiz, efendimiz, gökyüzü ve yeryüzü şanınızla doludur!” (Asturias, 2000: 114-115) cümlesi; Cara de Ángel'i tanımlamak için eser boyunca birçok kez tekrarlanan "şeytan kadar kötü, şeytan kadar güzel” ifadesi ve kimi sahnelerde yer alan Bakire Meryem tabloları gibi ögeler de Hristiyanlığı çağrıştıran diğer örneklerdir. Maya mitolojisi ise eserde daha geniş yer tutar ve diktatör ile Tohil arasında kurulan özdeşlik açıkça fark edilir. Ateş tanrısı Tohil, Mayaların kutsal kitabı Popol Vuh'ta anlatılanlara göre, kabilelere ateşi hem veren hem de geri alandır. Ateş isteyen kabilelere insan kurban etmelerini şart koşar. Tohil ile ona muhtaç bir biçimde yakaran ve hayatta kalmak için diğerini katlederek Tohil'e insan kurban eden kabileler arasındaki ilişki, eserde, diktatör ile toplum arasındaki ilişkiyi sembolize eder.

Eserin yapısında, bu mitolojik göndermelerin yanı sıra, simgesel anlamlar taşıyan kavramsal çatışmalar da dikkati çeker. İyi/kötü, aydınlık/karanlık ya da gerçek/yalan olarak oku- 
run karşısına çıkan söz konusu çatışmalar, olay örgüsünün akışı içinde birbiriyle örtüşen ve birbirini tamamlayan nitelikte gelişir. Eserin ilk sayfalarında erken anlatım olarak verilen "aydınlığın karanlık, karanlığın aydınlık içindeki çifte hoşnutsuzluğu” (Asturias, 2000: 7) ifadesi, anlatıyı yönlendiren bu karşılıklı ilişkiyi ve roman evreninin içinde bulunduğu gerçekliği özetler niteliktedir. Cara de Ángel'in cezaevine götürüldüğü bölümde yazar, insanın 1şığa olan ihtiyacını ve karanlığın yoğunluğunu vurgularcasına Cara de Ángel'in kapatıldığ1 zindanı "iki saat 1şık, yirmi iki saat zifiri karanlık" (Asturias, 2000: 331) içinde bir yer olarak tanımlar. Romanın Ojo de vidrio (Cam Göz) adını taşıyan IX. bölümünde ise benzer doğrultuda bir anlam vurgulanır. Işığa (ya da hakikatlerin hüküm sürmesine) izin vermeyen, karanlıktan beslenen ve karanlıkla büyüyen bu göz şeytanın, diğer bir ifadeyle, diktatörün gözünü simgeler. Tüm roman boyunca herkesi izler, her şeyi yutar ve yok eder:

"Bir göz... Yalnızca bir göz... (...) Bir kuşun yüreğinden büyük değildi ama cehennemden daha korkunçtu. (...) Fedina 1şığı söndürünce daha da kötü oldu; göz karanlıkta öyle bir hızla büyüdü ki, birkaç saniye içinde her şeyi yuttu: evin duvarlarını, döşemesini, tavanını, diğer evleri, yaşamını, oğlunu... Hayır, bu Tanrı'nın gözü değildi, şeytanın gözüydü’ (Asturias, 2000: 70-71).

Ayrıca, yazarın acımasız bir gerçeklik içinde betimlediği dilencilerin dünyası, Başkan'ın otoriter rejiminin yozlaşmış düzenini sembolize eder ve esere hakim olan yaşam biçiminin bir örneklemi gibidir. Toplumsallıktan uzak bir biçimde bireysel çıkarlar doğrultusunda hareket etmeyi ve bu sebeple, şeytani bir rejimin kuklası durumunda yaşamayı anlatır: "Birbirlerine yardımcı oldukları duyulmuş, görülmüşs şey değildi. Bütün dilenciler gibi sahip oldukları konusunda cimriydiler; kader ortaklarına bir şey vermektense köpeklere vermeyi tercih ediyorlardı" (Asturias, 2000: 8). Bununla birlikte, dilencilerin son derece gelişigüzel gerçekleşen ölümleri de rejimin yaşam hakkının kutsallığına ve dokunulmazlığına karşı gösterdiği saldırganlığı ve kayıtsızlığı gösterir. Anlatıcı ülkedeki bu durumu -şans eseri hayatta kalabilmeyiilerleyen sayfalarda şu sözlerle dile getirir: "Bu toprakların tek kanunu, şanslı olup olmadığınızdır. Şans eseri hapse düşebilirsiniz, idam edilebilirsiniz ve yine şans eseri milletvekili, diplomat, devlet başkanı, general ya da bakan olabilirsiniz!” (Asturias, 2000: 123)

Son olarak, bu kadar çok karanlığın ve kötülüğün olduğu eserde -bir süreliğine olsa da- umudu simgeleyen tek roman kişisi Öğrenci'dir. Sadece dört kez anlatıya dahil edilen Öğrenci karakteri yazarın umududur ${ }^{11}$ ve bu nedenle romanın karanlık evreninde yalnızca o 1şığı görür (ya da görmek ister). Kendisiyle aynı hücrede kalan diğer tutukluların, bulundukları durumdan kurtulmak için dua etmekten başka çarelerinin olmadığı şeklindeki tutumlarına karşı çıkar: "Dua etmek de ne demek! Dua etmemeliyiz! Bu kapıyı kırmalı ve devrim yapmalıyı!" (Asturias, 2000: 242) Ancak Asturias, bir yandan da geleceğe dair umutsuz ve kötümserdir. Zira Öğrenci'nin mücadele etmesi gereken teslimiyet sadece dışarıda değil, aynı zamanda içeridedir, kendi evinin içindedir; annesinin ve daha önceki nesillerin zihnine sirayet etmiştir. Bu yüzden Öğrenci, romanın bitişinde "çıkmaz bir sokağın sonunda" (Asturias, 2000: 340) bulunan evine gider ve annesini evde çaresizce Tanrı'ya yakarırken bulur: "Tanrım merhamet et" (Asturias, 2000: 340). Yazar bir yandan kapıları kırarak devrim yapmaktan bahsederken diğer yandan Öğrenci’ye olan inancında çelişkiler yaşar ve kapıldığı 
umutsuzluk ile bir bakıma kendi zihninde diktatöre yenik düşer. Böylece eserin ilk bölümünde Tanrı'nın Kapısı'nda başlayan kaos ve karanlık ortam çıkmaz bir sokakta son bulur.

Oldukça gerçekçi bir zeminde ilerleyen Teke Şenliği ise diktatörü olağanüstüleştirerek gökyüzüne çıkarmak yerine yeryüzüne indiren bir eserdir. Anlatıda diktatörü temsil eden mitolojik simgeler geniş yer tutmaz. Aksine Trujillo artık cinsel gücünü kaybetmiş, hatta idrarını tutamaz duruma gelmiş yaşlı ve hasta biridir. Urania ile geçirdiği, utanç ve öfke içinde defalarca hatırladığ 1 o gece, bir dönemin sonunu işaret eder ve eserin ilk sayfalarından itibaren bir leitmotiv olarak yer alır. Diğer bir deyişle, diktatörün iktidarsızlaşması onun sembolik olarak ölümüdür ve bu çeşit bir simgesel anlatımla başlayan eserde Vargas Llosa'nın, diktatörü tanrılaştırmak/mitleştirmek yerine onu gerçekçi bir zemine yerleştirerek insana özgü kusurlarla ifade etme amacında olduğu görülür. Halk arasında Teke, Velinimet, Yeni Vatan'ın Babası, Generalísimo gibi lakaplarla anılan diktatöre atfedilen tanrısal özellikleri ve bu tanrısallık imajını mümkün olduğunca kırmaya çalışır.

Cinsel zorbalığı ve kaba tavırları nedeniyle Dominik toplumunda Trujillo'ya atfedilen (Mateo, 2004: 203) ve Vargas Llosa'nın esere taşımış olduğu Teke (El Chivo) lakabı ise simgesel (ve mitolojik) bir anlama sahiptir. Trujillo karakterinin kadınlarla ilişkilerinde sergilediği zorbaca davranışlar ve bunu tüm çevresine dayatıyor oluşu, Antik Yunan mitolojisinde yer alan Teke-Tanrı ile benzerlik gösterir. Mitolojide küçükbaş hayvanların ve çobanların tanrısı olan keçi ayaklı Teke-Tanrı (Pan), birdenbire, beklenmedik gürültüler kopararak ortaya çıktığı için etrafta panik yaratır, korkular saçar ve azgın bir biçimde güzel perilerin peşine düşer (Necatigil, 1989: 52). Belden yukarısı insan, aşağısı ise teke şeklinde olan Pan'ın aşırı cinsel isteği ve baskın gücü onun en belirgin özelliğidir:

“(...) Çirkinliği ve kabalığı yüzünden, cinsel eş olarak tercih edilmez. Çiftleşmesi hep zor ya da hile gerektirir. Doymayan şehveti ve tükenmeyen eril gücüyle dağ, orman ve su perilerinin, çobanların ve hayvanların, kadın-erkek ayırt etmeden her rastladığının peşinden koşmak, bazen tecavüz etmek Pan'ın doğasıdır” (Saydam, 2008: 23).

\section{Sonuç}

Diktatörlüklerin Latin Amerika'da giderek yaygınlaşması ve öne çıkmasıyla birlikte yoğunlaşan diktatör/diktatörlük romanları hem toplumsal hem siyasal açıdan birçok veri sunarlar. İlk örneklerinden bugüne, toplumun ve diktatörün birbirine bakışını yansıtmaları, diktatöre yüklenen mitoloji ve olağanüstülüğü kimi zaman deforme ederek kimi zaman ise gülünçleştirerek görünür kılmaları, korkuyu ve itaati çeşitli biçimlerle ele almaları ve böylece tarihsel, toplumsal, siyasal bir sürece 1şık tutmaları bakımından önem taşırlar. Kurgu ile gerçeğin tutarlı bir biçimde bir araya getirildiği bu eserler, toplumsal ve psikolojik yönü ağır basan birçok mesajla yüklüdür ve diktatörlüğün birey ile toplum üzerinde yarattığı etkileri çarpıcı bir biçimde sahnelerler.

$\mathrm{Bu}$ çalışmada incelenen iki eser de otoriter rejimlerin yol açtığı zulüm, şiddet, işkence, adaletsizlik, yaşamın değersizliği gibi toplumsal sorunlara değinerek insanın rejim karşısındaki çaresizliğine ve korkutulmuş, bölünmüş, birbirine yabancılaşmış ve düşmanlaşmış bir topluma dikkat çekmektedir. Eserlerde yer alan toplumlar derin bir yozlaşma ve yabancılaşma içinde 
kapana kısılmış bir haldedir. Bay Başkan'da yabancılaşma, şiddet ve işkence, adaletsizlik, iletişimsizlik, korku, tutsaklık ve ölüm toplumsal açıdan öne çıkan anahtar kavramlarken, Teke Şenliği’nde, tüm bunlara ek olarak, cinsellik ile robot uyumluluğu da yer bulur. Bu bağlamda, Asturias ile Vargas Llosa'nın gerçeğe uygun birer roman evreni yarattığ likle örtüşen olayları ya da ilişkileri, hem bir metin içi tutarlılık oluşturarak hem de eseri kuşatan toplumsal bağlantıları kurarak öyküledikleri görülmektedir. Diğer bir deyişle -Goldmann’ın belirttiği gibi- her iki eserde de bir yandan kendi iç tutarlılıkları doğrultusunda anlam yaratan yapılar meydana getirilmiş, diğer yandan da bütünü oluşturan toplumsal ilişkiler ve bu ilişkileri meydana getiren süreçler bu iç yapıyla örtüşecek şekilde kurgulanmıştır.

\section{Notlar}

1 Bu bölümde Fransız edebiyat kuramcısı Gérard Genette'in 1972 yılında kaleme aldığı Anlatının Söylemi: Yöntem Hakkında bir Deneme (Discours du Récit: Essai de méthode) adlı eserinde yaptığı tanımlamalardan ve kullandığı terimlerden faydalanılmıştır.

2 Olacakları önceden haber veren bu ipuçları Gérard Genette'in kullandığı terminolojiyle ifade edecek olursak birer prolepsis (foreshadowing, öngörü, ileri atlama) örnekleridir.

3 Mario Vargas Llosa 1997 yılında yazdığı ve roman sanatı hakkındaki düşüncelerini aktardığı Cartas a un Joven Novelista adlı kitabında bu belirsiz anlatıcı konusuna değinir ve karmaşık gibi görünse de aslında temelde üç çeşit anlatıcı türü olduğunu söyler: Karakter anlatıcı, anlattığı öykünün dışında bulunan tanrısal anlatıcı ve anlattığı dünyanın dışında olup olmadığı çok net anlaşılamayan belirsiz anlatıcı. Yazarın hangi anlatıcı türünü seçtiğini anlamak içinse hangi kişi adılının kullanıldığına bakılması gerektiğini belirtir. Anlatıcı "ben" ya da "biz" kişisini kullanıyorsa karakter anlatıcı, "o" kişisini kullanıyorsa tanrısal anlatıcıdır. Ancak, "sen" kişisini kullanması durumunda bu belirsiz bir anlatıcıdır (Vargas Llosa, 1997: 33-35).

4 Hysteron proteron yöntemi: Zamanın takip etmesi gereken doğal ya da mantıksal sıranın bozularak yerinin değiştirilmesi.

5 "Esperpento: 1. Grotesk ve gülünç olan; 2. Ramón del Valle-Inclán tarafindan yaratılmış, gerçekliğin, grotesk yönlerinin öne çıkarılarak, gündelik ve kaba bir dilin kullanımıyla deforme edildiği üslup; 3. (gündelik dilde) çirkinliği, dağınıklığı ya da kötü görünümüyle dikkat çeken kişi ya da nesne" (Esperpento, t.b.).

6 Calié: Trujillo döneminde Askeri İstihbarat Teşkilatı bünyesinde çalışan ajanlara halk arasında verilen ad.

7 Mosco'nun durumu buna en bariz örnektir. Görgü tanığı olarak sorgulanır ve gerçeği söylemekte direndiği için polis tarafindan öldürülür. Ancak bu durum oldukça saçmadır çünkü Mosco kördür.

8 Trujillo'nun bu durumu, George Orwell'in Bin Dokuz Yüz Seksen Dört adlı siyasi romanında da bahsetmiş olduğu ilk gece hakkın (jus primae noctis) anımsatır: “(...) Bir de jus primae noctis diye bir şey vardı ki, çocukların ders kitaplarında geçmesi sakıncalıydı. Kapitalistlere, fabrikalarında çalışan her kadınla yatma hakkı tanıyan bir yasaydı bu. Bunların ne kadarının yalan olduğunu nasıl bilecektiniz ki? Sıradan insanların artık Devrim'den önceki dönemden daha iyi durumda oldukları doğru olabilirdi” (Orwell, 2010: 93).

9 İkili bilinç (dual consciousness): Görünüşte birbirine göre tutarsız olan iki inanç sistemine aynı anda inanan insanların dünya görüşünü karşılamak üzere kullanılan bir terim. İkili bilinç, genellikle, insanların genel toplumsallaşmanın etkisiyle egemen kültürün inançlarını benimsemeleri ama yaşamdaki kendi pratik deneyimlerine dayanarak da başka bir inanç sistemine sahip olmaları durumuna atfedilmektedir. İş̧i sınıfının, gündelik deneyiminin toplumun benimsediği inançlara aykırı düşmesi nedeniyle ikili bilince en eğilimli kesim olduğu genel bir kanıdır. Örneğin, bu doğrultuda işçilerin, grevlerin genellikle kötü niyetlilerin, aşırıların ve ajitatörlerin kışkırttığı eylemler olduğunu kabul etmeleri (benimsenen inançlar) ama kendi grev deneyimlerini gerçek şikayetleriyle birleştirmeleri (pratik deneyimler) mümkündür (Marshall, 1999: 326-327).

10 Mestizo: Avrupalı ile yerli anne-babanın çocuğu, melez.

11 Bu karakterin, öğrencilik yıllarında kendisi de hapse atılan yazarın alter-egosu olduğu düşünülebilir. 


\section{Kaynakça}

Abalos, D. T. (1993). The Latino family and the politics of transformation. Praeger.

Almoina, J. (2011). Una satrapía en el Caribe. Siglo XXI.

Asturias, M. Á. (2000). El Señor presidente (G. Martin.Ed.) Miguel Ángel Asturias: El Señor Presidente içinde (1-340). Fondo de Cultura Económica.

Canetti, E. (2006). Kitle ve iktidar (G. Aygen. Çev) Ayrıntı.

Elias, N. (1983). The court society. Pantheon Books.

Feliu-Moggi, F. (2000). A través del espejo: El Señor Presidente y Miguel Ángel Asturias en la Guatemala de Jorge Ubico (G. Martin. Ed.) Miguel Ángel Asturias: El Señor Presidente içinde (566-612). Fondo de Cultura Económica.

Fromm, E. (2016). Özgürlükten kaçış (Ş. Yeğin. Çev.) Say.

Goldmann, L. (2005). Roman sosyolojisi (A. Erkay. Çev.) Birleşik.

Gürsel, N. (2007). Başkaldıran edebiyat. Doğan.

Himelblau, J. (2000). Chronologic deployment of fictional events in Miguel Ángel Asturias's El Señor Presidente (G. Martin.Ed.) Miguel Ángel Asturias: El Señor Presidente içinde (1008-1029). Fondo de Cultura Económica.

Hübner, M. E. (1992). Guatemala en la historia: Un pueblo que se resiste a morir. Parrilla Barascut. Kıran, A. E., Kıran, Z. (2011). Yazınsal okuma süreçleri. Ankara: Seçkin.

Marshall, G. (1999). Sosyoloji sözlüğü (O. Akınhay ve D. Kömürcü. Çev.) Bilim ve Sanat.

Mateo, A. L. (2004). Mito y cultura en la era de Trujillo. Manatí.

Navarro, C. N. (1969). La desintegración social en el Señor Presidente. Revista Iberoamericana. 35 (67): 59-76.

Necatigil, B. (1989). 100 soruda mitologya. Gerçek.

Orwell, G. (2010). Bin dokuz yüz seksen dört (C. Üster. Çev.) Can.

Ospina, C. W. (1929). El autócrata: Ensayo político-social. Guatemala: Tipografía Sánchez\&de Guise.

Pineda C., F. (1902). Para la historia de Guatemala: Datos sobre el gobierno del licenciado Manuel Estrada Cabrera. University Michigan Library.

Rifat, M. (2008). XX. yüzyılda dilbilim ve göstergebilim kuramları. Tarihçe ve eleştirel düşünceler. YKY.

Rifat, M. (2005). XX. yüzyılda dilbilim ve göstergebilim kuramlart. Temel metinler. YKY.

Rodríguez Gómez, J. C. (2000). Miguel Ángel Asturias: Una estructura del subdesarrollo. (G. Martin, Ed.) Miguel Ángel Asturias: El Señor Presidente içinde (812-822). Fondo de Cultura Económica.

Saydam, M. B. (2008). Acı ve hışım. Panik kavramına psikomitolojik değinmeler. Başka Psikiyatri ve Düşünce Dergisi. 1: 22-35.

Vargas Llosa, M. (1997). Cartas a un joven novelista. Planeta.

Vargas Llosa, M. (1975). La orgía perpetua, Flaubert y Madame Bovary. Barcelona: Seix Barral S.A. Vargas Llosa, M. (2003). Teke şenliği (P. B. Charum.Çev.) Can.

Villalona, A. S. (2012). La dictadura de Trujillo. Búho S. R. L.

\section{Elektronik kaynaklar}

Esperpento. (t.b.). Real Academia Española. Diccionario de la lengua española içinde. http://bit. ly/1OkYFAl. 